\title{
Evolution and Medical Significance of LU Domain-Containing Proteins
}

\author{
Julie Maja Leth ${ }^{1,2}$, Katrine Zinck Leth-Espensen ${ }^{1,2}$, Kristian Kølby Kristensen 1,2, \\ Anni Kumari 1,2, Anne-Marie Lund Winther ${ }^{1,2}$, Stephen G. Young ${ }^{3,4}$ and Michael Ploug 1,2,*(D) \\ 1 Finsen Laboratory, Ole Maaloes Vej 5, Righospitalet, DK-2200 Copenhagen, Denmark; \\ Julie.Maja@finsenlab.dk (J.M.L.); katrine.espensen@finsenlab.dk (K.Z.L.-E.); \\ kristian.kristensen@finsenlab.dk (K.K.K.); Anni.Kumari@finsenlab.dk (A.K.); \\ Anne.Marie@finsenlab.dk (A.-M.L.W.) \\ 2 Biotechnology Research Innovation Centre (BRIC), Ole Maaloes Vej 5, University of Copenhagen, \\ DK-2200 Copenhagen, Denmark \\ 3 Department of Medicine, University of California, Los Angeles, Los Angeles, CA 90095, USA; \\ sgyoung@mednet.ucla.edu \\ 4 Department of Human Genetics, University of California, Los Angeles, Los Angeles, CA 90095, USA \\ * Correspondence: m-ploug@finsenlab.dk; Tel.: +45-3545-6037
}

Received: 25 April 2019; Accepted: 4 June 2019; Published: 5 June 2019

\begin{abstract}
Proteins containing Ly6/uPAR (LU) domains exhibit very diverse biological functions and have broad taxonomic distributions in eukaryotes. In general, they adopt a characteristic three-fingered folding topology with three long loops projecting from a disulfide-rich globular core. The majority of the members of this protein domain family contain only a single LU domain, which can be secreted, glycolipid anchored, or constitute the extracellular ligand binding domain of type-I membrane proteins. Nonetheless, a few proteins contain multiple LU domains, for example, the urokinase receptor UPAR, C4.4A, and Haldisin. In the current review, we will discuss evolutionary aspects of this protein domain family with special emphasis on variations in their consensus disulfide bond patterns. Furthermore, we will present selected cases where missense mutations in LU domain-containing proteins leads to dysfunctional proteins that are causally linked to genesis of human disease.
\end{abstract}

Keywords: uPAR; snake venom $\alpha$-neurotoxins; GPIHBP1; plesiotypic disulfide bonds; protein evolution; Ly6/uPAR domains; protein module; protein domain

\section{Introduction}

Protein domains are autonomous folding units that may function alone or as building blocks in the context of multidomain proteins. When such protein domains are encoded by exons flanked by introns of identical phases, they may become genetically mobile and prone to exon shuffling, resulting in the insertion of a domain into a non-homologous protein environment. This process is facilitated by intronic recombination [1]. Highly mobile protein domains are termed protein modules. Examples of protein modules that occur in multidomain proteins include kringle domains, growth-factor-like domains (GFD), fibronectin type I-III (FN1, FN2, and FN3) domains, immunoglobulin domains (Ig), and complement control protein (CCP) domains [1,2]. Along with single-gene or large-genome duplication events, exon shuffling provides a rich source for the evolutionary diversification and neo-functionalization of a given protein domain. The current review focuses on one such domain-the Ly6/uPAR (LU) protein domain. In an evolutionary context, LU domain proteins occur in a wide range of eukaryotic taxa and come in a variety of different flavors: i) as secreted single domain proteins; ii) as glycosyl-phosphaditylinositol (GPI-anchored) single domains; iii) as GPI-anchored 
multidomain proteins; and iv), as the extracellular ligand-binding domain in the TGF- $\beta$ receptor family of transmembrane proteins. In this review, we will predominantly focus on deletions of plesiotypic (ancestral) disulfide bonds and acquisitions of apotypic (non-consensus) disulfide bonds in LU domain-containing proteins and discuss some possible functional consequences thereof. In a functional context, these proteins participate in a diverse array of different biological processes such as fertilization, regulation of complement activity, intravascular lipid metabolism, fibrinolysis, cytokine signaling, envenomation, limb regeneration, embryogenesis, and morphogenesis. To illustrate the functional diversity of LU domain-containing proteins, we will discuss evolution, function, and medical relevance of selected members of this protein domain family.

\section{Consensus Structures Defining LU Domains}

Genes encoding LU domain proteins typically contain three exons: One for the N-terminal signal sequence followed by a set of two exons for the mature LU domain-generally flaked by phase-1 introns-thus facilitating genetic mobility (Figure 1A). Consistent with this composition, genes encoding LU-domain proteins often appear in small clusters in contiguous loci where they maintain their general intron-exon structure, as shown in Figure 1A. Such clustering of genes would suggest that an evolutionary expansion and diversification of this gene family occurred via multiple gene-duplication events. Accordingly, Loughner et al. [3] found that 30 out of the $48 \mathrm{LU}$ containing-proteins in the human genome are located in just four small gene clusters. These segments are located on chromosomes 6p21 (LY6G6C, LY6G6D, LY6G6F, LY6G5C, and LY6G5B), 8q24 (PSCA, LY6K, SLURP1, LYPD2, LYNX1/SLURP2, LY6D, GML, LY6E, LY6L, LY6H, and GPIHBP1), 11q24.2 (ACRV1, PATE1, PATE2, PATE3, and PATE4), and 19q13 (LYPD4, CD177, TEX101, LYPD3, PINLYP, PLAUR, LYPD5, and SPACA4); the latter gene cluster includes all proteins in the human genome known to contain multiple LU domains [4]. The remaining LU domain encoding genes are more or less scattered in the human genome (i.e., LYPD1, LYPD6, LYPD6B, LYPD8, CD59, BAMBI, ACVR1, ACVR1A, ACVR1B, ACVR1C, ACVR2A, ACVR2B, ACVRL1, BMPR1A, BMPR1B, BMPR2, TGFBR1, and TGFBR2).

The consensus sequence defining the primordial LU domain comprises 60-90 residues with 10 plesiotypic cysteine residues engaged in a stereotypical disulfide-bonded network: $1-5,2-3$, $4-6,7-8$, and 9-10, as depicted by the sequence alignment of LU domains from different metazoan classes in Figure 1B. A non-glycosylated asparagine residue invariably follows the tenth cysteine in the LU domain signature. Notwithstanding the conservation of the LU domain signature, a high sequence diversity and a high propensity for undergoing lineage-specific expansion, diversification and neo-functionalization are the evolutionary hallmarks driving the functional versatility within this protein-domain family $[5,6]$. In some cases, this diversification and neo-functionalization even led to an erosion of the original plesiotypic disulfide pattern defining the LU domain, as illustrated in later sections. In particular, deletions of the 2-3 disulfide bond often occurred during this process (Section 3.1), but in very rare cases the 7-8 disulfide bond was also deleted (Section 4.3). Furthermore, additional apotypic disulfide bonds have occasionally been introduced into the LU domain scaffold.

Another salient feature of all LU domains is their unique protein-folding topology, where a cysteine-rich core projects three long $\beta$-hairpins (i.e., loops 1,2 , and 3 ) that assemble into a slightly curved central $\beta$-sheet, thus forming the dominating secondary structure of the characteristic three-fingered fold (Figure 1C). The six strands forming these three loops are designated A-F in the order of appearance in the primary sequence. These strands have a high propensity for forming $\beta$-sheets, with the exception of strand E, located at the edge of the LU domain, which can be flexible and adopt random coils, $\beta$-strands, or $\alpha$-helices. The last disulfide bond (denoted 9-10) forms a small loop on the "back" of the central $\beta$-sheet, where it either terminates the LU domain in secreted proteins (Section 4.1) or extends into a carboxyl-terminal GPI-moiety that tethers the LU domain to the cell membrane in glycolipid-anchored variants (Section 4.2). The position of the intron, which divides the exon set encoding the mature LU domain, corresponds to the tip of loop 2 in the mature protein. 
The protruding loops and the concave face of the central $\beta$-sheet of the LU domains are generally involved in protein-protein interactions [7-10].

A

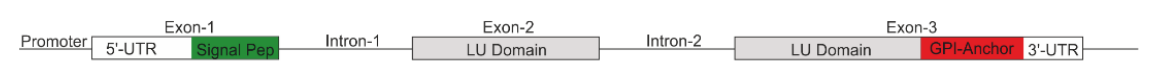

B

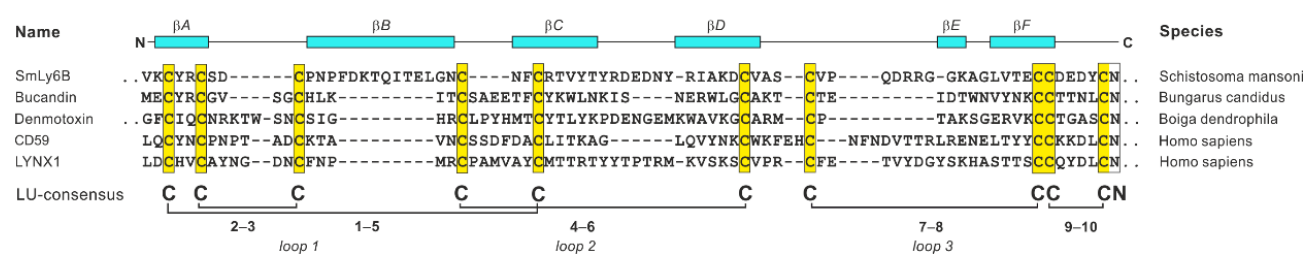

C

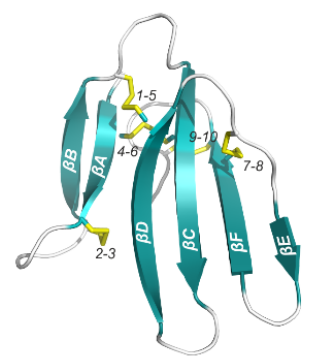

Bucandin

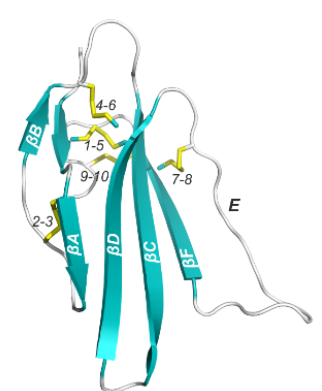

LYNX1

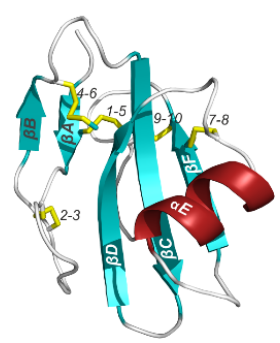

CD59

Figure 1. Characteristic properties of typical LU-domain encoding genes and their protein products: (A) The gene structure encoding an archetypical single LU-domain protein comprises three exons. Note that the signal sequence for GPI-anchoring is included in exon-3 for those proteins that are destined to become glycolipid anchored. (B) Sequence alignments of typical LU domains from different metazoan taxa where the plesiotypic 10-cysteine pattern is maintained (highlighted by yellow boxes along with the consensus disulfide bonding). Typical LU-domain secondary structure elements are shown in the top of the alignment as cyan boxes using the structure of Bucandin as reference. SmLy6B (Uniprot: B8Y6H3) from Schistosoma mansoni represents the class Trematoda [11]; Bucandin (Uniprot: P81782) from Bungarus candidus and Denmotoxin (Uniprot: Q06ZW0) from Boiga dendrophilae both represent the class Reptilia; CD59 (Uniprot: P13987) and LYNX1 (Uniprot: P0DP58) from Homo sapiens both represent the class Mammalia. Dots indicates an extension of the sequence. (C) The three dimensional protein structures of prototypical single LU-domain proteins are represented in a cartoon representation for CD59 [PDB 2OFS [12]], LYNX1 [PDB 2L03 [13]], and Bucandin [PDB 1F94 [14]]. The plesiotypic disulfide bonds are shown as yellow sticks and are numbered as in panel (B). The protruding strands forming the three loops are labelled $A-F ; \beta$-sheets are colored cyan; $\alpha$-helices are colored red.

\section{Non-Mammalian LU-Domain Proteins}

Although genes encoding LU-domain proteins are recognized in almost all phyla of the metazoan kingdom [15] and proteomics have revealed their presence in coelomic fluids of Echiodermata [16], we will only focus on a few examples of non-mammalian LU-domain proteins that have contributed significantly to our understanding of the evolutionary origin of the functional and structural diversity of LU domains.

\subsection{Snake Venom $\alpha$-Neurotoxins}

Toxins from venomous snakes provide a rich source of information on the evolution of LU-domain containing proteins, in particular with a view to sequence diversification and neo-functionalization of $\alpha$-neurotoxins. The co-evolutionary "arms race" between snake venom $\alpha$-neurotoxins and their specific target proteins within the cholinergic system of their agile prey which they need to subdue provides a unique setting dominated by gene duplications and sequence evolution under positive Darwinian selection [6]. Extensive data mining of the numerous sequences from three-fingered toxins (more than 
700 are known) has provided a unique insight into the rapid evolution and neo-functionalization of this scaffold. In this section, we will emphasize the diversification of the plesiotypic disulfide bonds in the snake toxins with respect to their specificity and efficacy in targeting essential receptors in their preferred prey.

Three-fingered toxins with the ancestral 10-cysteine LU-domain signature are the main constituent in venom from the advanced non-front fanged snake lineages (e.g., the genus Boiga in the family Colubridae). These toxins are often misclassified as "weak neurotoxins" due to their low toxicity towards synapsid targets (mammals). This is clearly a misnomer, since they are potent inhibitors of the cholinergic system of diapsids, which makes sense as these snakes feed primarily on birds, reptiles, and amphibians. Basal-type $\alpha$-neurotoxin is, thus, a more appropriate terminology for these toxins, referring to their primordial phylogenetic origin. Within the framework for LU domains, an atypical covalently linked heterodimeric toxin, irditoxin [17], arose in the Colubridae family (Figure 2). From an evolutionary perspective, this represents an interesting case as the introduction of an eleventh cysteine into the LU domain occurred at different positions in the two subunits forming the heterodimeric irditoxins. It is likely that these changes occurred in concert, given that mutations introducing free cysteines in secreted proteins rarely survive selection because of the deleterious effects of the reactive free thiol group [18]. Irditoxin possesses a high taxon-specific lethality, since its blockage of avian neuromuscular junctions is 1000-fold more potent than blockage of the corresponding neuromuscular junctions in mammals [17]. The evolution of irditoxin-a toxin that is more potent than the single LU-domain toxin denmotoxin-is probably among the driving factors for the "success" of Boiga irregularis as an invasive species in the Pacific island of Guam [17,19].

An impressive radiation in toxin diversification and potency towards synapsids arose in the advanced snake lineage Elapidae subsequent to the anatomical acquisition of a high-pressured and hollow front-fanged venom-delivery system. Evolution of this delivery system was tightly associated with the neofunctionalization of three-fingered toxins. This occurred primarily via the selective deletion of one plesiotypic LU-domain disulfide bond-the one that stabilizes loop 1 and is denoted 2-3 in Figures 1 and 2. One hypothesis proposes that the loss of the structural constraints from this disulfide bond created a more flexible toxin scaffold, which subsequently facilitated neo-functionalization by rapid diversification of surface exposed residues [6]. The resultant 8-cysteine LU-domain scaffold contributed to high potency towards many mammalian targets, resulting in the notorious toxicity of elapid snake venom in humans. Short-chain $\alpha$-neurotoxins gained high potency towards mammalian nicotinic acetylcholine receptors $(\alpha 1 \mathrm{nAChR})$, breaching the taxon-specific lethality for the toxins found in colubrine snakes with the complete 10-cysteine LU-domain signature. The introduction of an apotypic disulfide bond at the tip of loop 2 in the LU domain of the long-chain $\alpha$-neurotoxins (Figure 2) further expanded their targeting repertoire to include $\alpha 7 \mathrm{nAChR}$. A subgroup of the long-chain $\alpha$-neurotoxins developed into non-covalent homodimeric toxins (e.g., $k$-bungarotoxin), which antagonizes the neuronal $\alpha 3 \beta 2 \mathrm{nAChR}$. Along the same lines, haditoxin [20], which is a homodimeric short-chain $\alpha$-neurotoxin, also exhibits a broad pharmacologic specificity by targeting muscle as well as several neuronal $\mathrm{nAChRs}(\alpha 7, \alpha 3 \beta 2, \alpha 4 \beta 2)$. The high adaptability of the 8-cysteine LU-domain scaffold for undergoing neo-functionalization is clearly illustrated by the wide range of targets that it can antagonize. Besides nicotinic acetylcholine receptor antagonists, these toxins can act as muscarinic acetylcholine receptor antagonists (MT7), acetylcholinesterase inhibitors (fasiculins), L-type calcium channel antagonists (calsiceptine), non-specific cytotoxins disrupting the phospholipid bilayer (cardiotoxins), or as modulators of the acid-sensing ion channels (mambalgins). Intriguingly, mambalgins exhibit no toxic effects, but by inhibiting the acid-sensing ion channels, they exhibit potent analgesic effects (comparable to morphine) without inducing tolerance or respiratory distress. This profile triggered considerable pharmacological interest in these LU-domain proteins as therapeutic agents to alleviate chronic pain $[9,21]$. 
A

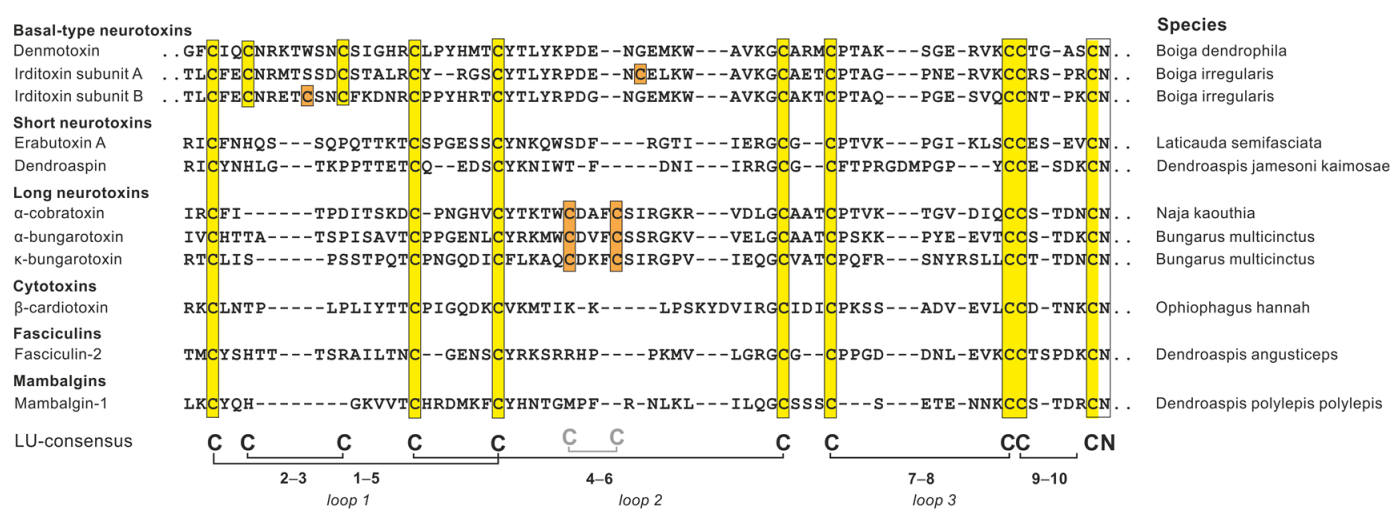

B
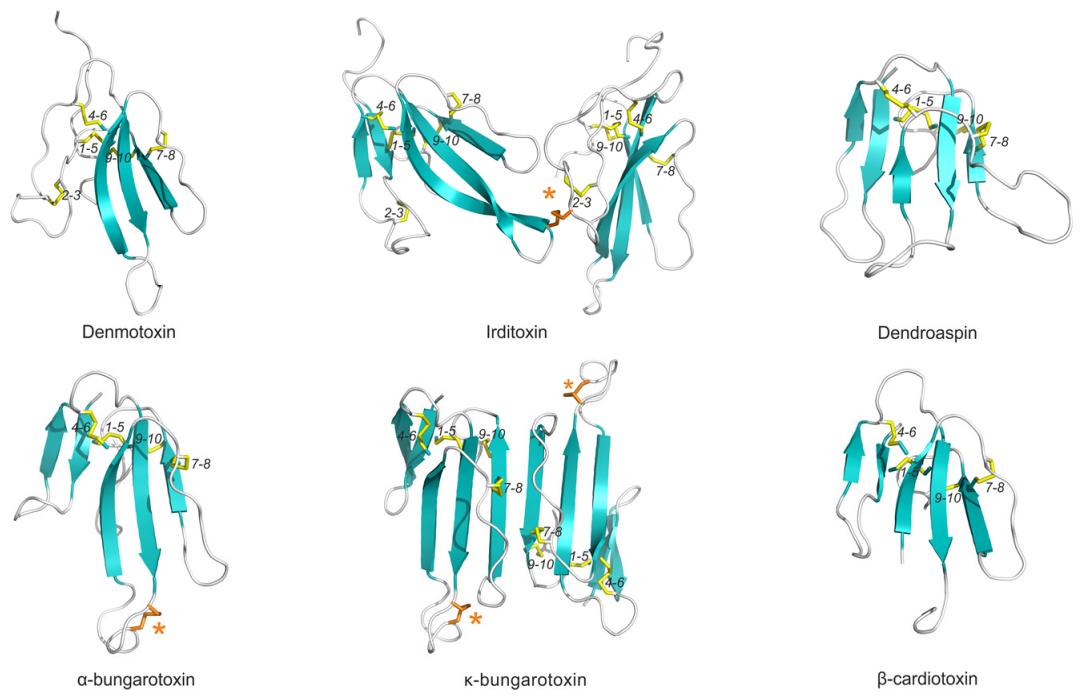

Figure 2. Evolution and neo-functionalization of LU domains from snake venom toxins: (A) A sequence alignment of typical members of the different groups of snake-venom toxins. Note, only the basal-type neurotoxins maintain the 2-3 disulfide bond. Orange boxes highlight apotypic cysteine residues and yellow boxes highlight plesiotypic LU-domain cysteine residues. Dots indicate sequence extensions. The apotypic, intra-domain disulfide bond in the long-chain $\alpha$-neurotoxins is included in the consensus sequence in light gray. (B) Three-dimensional structures of selected LU domains belonging to basal-type $\alpha$-neurotoxins [denmotoxin (PDB 2H5F [22]); irditoxin (PDB 2H7Z [17])], short-chain $\alpha$-neurotoxins [dendroaspin (PDB 2LA1 [23])], long-chain $\alpha$-neurotoxins [ $\alpha$-bungarotoxin (PDB 1HC9 [24]); k-bungarotoxin (PDB 1KBA [25])], and cytotoxins [ $\beta$-cardiotoxin (PDB 3PLC)]. The apotypic disulfide bonds in the long-chain $\alpha$-neurotoxins and irditoxin are marked with an asterisk.

Of note, a dynamic recruitment of genes to the postorbital venom gland appears to have evolved by distinct co-option events of genes expressed in other tissues that are supporting normal physiological processes [26-28]. That concept-where LU domains with normal and toxic functions could have a shared phylogenetic ancestry-is consistent with the observation that LYNX1 (Figure 1) and SLURP1 (Section 4.1), both prototypical LU domains with 10 cysteine residues, have modulatory roles on $\mathrm{nAChR}$ activities in the normal brain [29,30] and skin [31], respectively. Such an evolutionary trajectory would be in accordance with the species-selectivity of the early snake-venom toxins for diapsid targets. In line with this theory for neurotoxin evolution, LU-domain proteins, involved in regulating the activity of acetylcholine receptors, are often referred to as endogenous prototoxins. One study demonstrated that expression of $\alpha$-bungarotoxin in zebrafish muscle fibers in vivo in a tethered version by adding a GPI-anchor specifically silenced muscle nAChR activity without having systemic toxicity or overt effects of neuromuscular synapse development, thus reverting this toxin into a "prototoxin-like" state [32]. 


\subsection{LU Domain Proteins in Drospohila}

LU domains are also widely expressed within the class Insecta, where their expression and function in Drosophilae has been studied intensively. The genome of Drosophila contains 45 genes encoding LU-domain proteins, all of which are predicted to be GPI-anchored [33]. As observed in other metazoan classes, Drosophilae genes encoding LU-domain proteins tend to cluster in specific regions of the genome, suggesting that they have arisen by multiple gene-duplication events and subsequent diversification $[5,34]$. More than half of these genes encode archetypical single LU-domain proteins with 10 cysteines and a C-terminal signal sequence for GPI-anchoring [33]. A few proteins contain multiple LU domains (ranging from 2 to 44 LU domains). Among these proteins, two contain LU domains with only 8 disulfide bonds (lacking the 7-8 plesiotypic disulfide bond), but their expression in vivo has not yet been verified [33].

From a functional perspective, four Drosophila genes encoding GPI-anchored proteins with a single LU domain (boudin, crooked, coiled, crimpled) have attracted considerable interest. These single LU-domain proteins play non-redundant roles in establishing the epithelial septate junctions in Drosophilae, which function as anatomical diffusion barriers equivalent to tight junctions in vertebrate epithelia $[33,35,36]$. The precise mode of action of these LU-domain proteins is unclear, but it may involve the trafficking of septate junction constituents such as Neurexin IV [35,36].

Interestingly, the Drosophila brain contains another GPI-anchored, single LU-domain protein resembling an endogenous prototoxin. This LU-domain protein, encoded by quiver/sleepless, possesses a remarkable dual functionality. It both antagonizes the $\mathrm{AAChR}$ encoded by redeye [37] and stimulates the voltage-gated potassium channel shaker [38]. These properties endow quiver/sleepless with the ability to modulate neuronal excitability and cholinergic synaptic transmission, serving to regulate sleeping patterns in Drosophila [39]. This observation suggests that the interaction between endogenous prototoxins and nAChRs is a more general phenomenon, present in metazoan classes as diverse as Mammalia (LYNX1) and Insecta (sleepless).

\subsection{LU-Domain Proteins in Teleosts}

From the standpoint of evolution, the wholesale genome duplication that occurred at the base of the teleost radiation provides another interesting case involving diversification of two paralogous genes. The fate of duplicated genes may entail neo-functionalization, functional conservation, or drift into a silenced pseudogene [40]. Although the study on teleost LU-domain proteins is in its infancy, it is clear that genomes of zebrafish and medaka contain small contiguous clusters of genes with the prototypical intron-exon structure of plesiotypic LU-domain proteins [41-45]. A cluster on zebrafish chromosome 21 encodes seven GPI-anchored proteins containing two consecutive LU domains [42]; six of these proteins are expressed primarily in the developing brain and one is expressed in the skin. Both LU domains in these proteins maintain the 10-cysteine signature. In contrast, all mammalian proteins containing multiple LU domains lack the 7-8 plesiotypic disulfide bond in the N-terminal LU domain (Section 4.3).

Herberg et al. [41] demonstrated that one GPI-anchored, single LU-domain protein, bouncer, is expressed on zebrafish oocytes and is required for fertilization, as it mediates the contact between the oocyte and the spermatocyte. The closest human homolog of bouncer is SPACA4/SAMP14 (sperm acrosomal membrane protein 14). Herberg et al. proposed that bouncer is one of the key components governing species-specific fertilization in teleosts. This conclusion is based mainly on cross-fertilization experiments after swapping the endogenous expression of bouncer in zebrafish oocytes with that of medaka. This swapping strategy allowed the entry of medaka sperm into zebrafish oocytes, albeit at a low efficiency. As illustrated in Figure 3, the gene encoding bouncer occurs in two paralogous forms ( $A$ and $B$ ) in medaka, due to the early gene duplication. One variant contains the 10-cysteine LU-domain signature (B), whereas the other (A) has lost the 2-3 plesiotypic disulfide bond that in snakes induced rapid diversification and neo-functionalization of the $\alpha$-neurotoxins (Section 3.1). Replacing the 10-cysteine LU-domain variant of zebrafish bouncer with the 8-cysteine LU-domain 
variant from medaka (A) may therefore have lowered the efficacy by which cross-fertilization occurred. It is possible that the B-form of medaka bouncer does not produce a correctly folded protein, as it contains an unpaired eleventh cysteine residue (Figure 3). As the A-variant of bouncer from Cyprinus carpio maintains a similar 10-cysteine LU-domain signature as that found in zebrafish bouncer, it would be interesting to test if the swapping protocol used by Herberg et al. would lead to a higher cross-fertilization efficacy between these species.

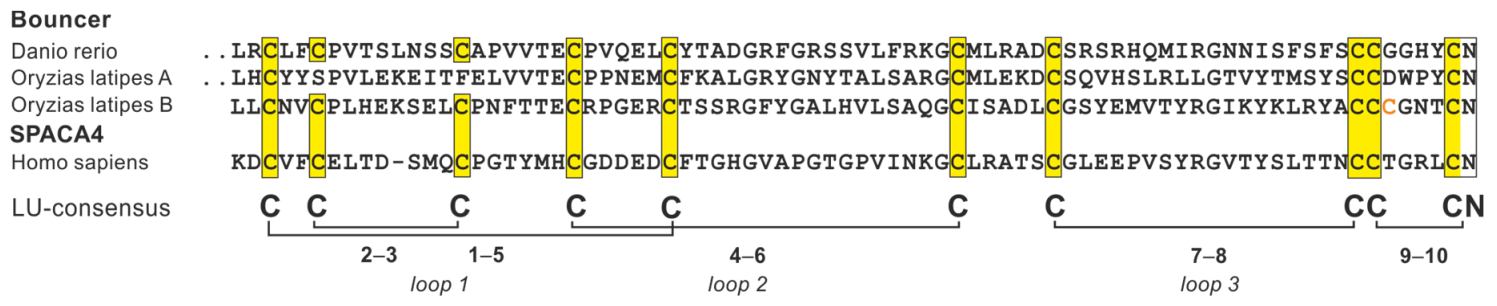

Figure 3. Sequence alignment of bouncer from zebra fish (Danio rerio) with two paralogous sequences (A and B) from medaka (Oryzias lapites). These proteins are expressed by oocytes. The B variant of medaka bouncer contains an unpaired cysteine (highlighted in orange) and lacks a functional C-terminal signal sequence entailing membrane tethering by a GPI-anchor. Also shown is the sequence from the closest human homolog, SPACA4/SAMP14, expressed in spermatocytes.

The importance of another gene (lypd6; LY6/PLAUR domain-containing 6) encoding a GPI-anchored LU-domain protein on early zebrafish development is also clearly documented [45]. By genetically manipulating lypd6, it was shown that this protein regulates embryonic mesoderm and neuroectoderm patterning by enhancing Wnt/ $\beta$-catenin signaling via binding to Lrp6 in lipid rafts [45]. Lypd6 contains an additional apotypic disulfide bond stabilizing its third loop (as illustrated by the structure of human LYPD6 in Figure 6D).

\section{Mammalian LU Domain Proteins}

\subsection{Secreted Single LU Domain Proteins}

Of the 48 genes encoding LU-domain proteins in the human genome, 11 encode a secreted version of a single LU-domain protein, such as SP-10, PATE 1-4, SLURP-1, and SLURP-2 (secreted Ly6/uPAR-related proteins). These secreted proteins retain the genetic and structural hallmarks of LU domains. Among the secreted LU-domain proteins, SLURP-1 has received the most attention, since missense mutations in that gene cause a rare autosomal-recessive skin disease, mal de Meleda [46]. Patients with mal de Meleda exhibit palmoplantar keratoderma with transgrediens. SLURP-1 is expressed primarily in the stratum granulosum of the epidermis [47]. Several of the missense mutations in SLURP-1 associated with mal de Meleda affect one of the 10 plesiotypic LU-domain cysteine residues (pCys77Arg, pCys94Ser, and pCys99Tyr [46]). These mutations grossly impair the folding of the LU domain, preventing efficient secretion from cells [48]. Deletions of either SLURP-1 or SLURP-2 leads to a mal de Meleda-like phenotype in mice and the combined double deficiency causes a comparable disease severity, as presented by the individual single deficiencies, suggesting that SLURP-1 and SLURP-2 either act together or act sequentially in the same pathway [49-51]. SLURP-1 inhibits keratinocyte proliferation in vitro by $40 \%$, presumably by antagonizing binding to the $\alpha 7-\mathrm{nAChR}$ with low nanomolar affinities [31], while SLURP-2 in contrast stimulates keratinocyte proliferation in vitro and presents a more promiscuous binding profile towards several AChRs [52]. Whether these effects are causally related to development of mal de Meleda remains unclear.

\subsection{Glycolipid-Anchored Single LU-Domain Proteins}

The majority of LU-domain proteins encoded in the human genome are GPI-anchored single-domain proteins with the 10-cysteine signature. Although protein structures and biological 
functions of a few of these proteins are well-characterized (e.g., CD59, GPIHBP1, LYNX1, LYPD6), molecular and functional insights into the majority of these family members are at best rudimentary.

\subsubsection{CD59}

One of the best-characterized proteins within this group is the complement regulatory protein CD59 (Figure 1). CD59 protects host cells from autologous complement damage by binding to the premature membrane attack complex $\mathrm{C} 5 \mathrm{~b}-8$, thus preventing maturation into the terminal pore-forming cytolytic complex. Phylogenetically, CD59 exhibits a broad taxonomic distribution in vertebrates, spanning from teleost to mammals, but CD59 is lacking in Cavia porcellus (guinea pig), where the CD59 gene has been transformed into a pseudogene [53]. A few rare cases of homozygous missense mutations leading to defective CD59 have been identified in humans [54-57]. These defects are associated with a life-threating prothrombotic phenotype with intravascular hemolysis, cerebral infarction, and relapsing peripheral neuropathy. The ability of rodents to withstand CD59 deficiency could be due to the protective activity of another complement regulatory component (Crry) in those species [58]. One of the two deleterious single-site missense mutations in human CD59 disrupts the 9-10 disulfide bond (pCys64Tyr). This mutation destabilizes CD59 folding and interferes with transport of the protein to cell surface [57], thus providing the molecular basis for its association with disease development.

\subsubsection{LYNX1}

Studies on mice with genetic ablation of Lynx1 reveal that this prototoxin limits neuronal plasticity in the adult visual cortex by attenuating the cholinergic response of $\alpha 4 \beta 2$ and $\alpha 7$ nAChRs $[29,59]$. Lynx 1 is widely expressed in a variety of neuronal subtypes in the brain where it colocalizes with $\alpha 4 \beta 2$ and $\alpha 7 \mathrm{nAChRs}[32,60]$. The progressive increase in Lynx1 expression in the visual cortex neurons of the developing brain thus gradually impair visual acuity after monocular deprivation (amblyopia) in adults versus juveniles, but importantly this limitation of adult mice is rescued by increased neuronal plasticity in Lynx1 deficient mice [29]. Pharmacological intervention via administration of an acetylcholinesterase inhibitor (physostigmine) also induces neuronal plasticity in the adult mouse brain [29]. The impact of Lynx 1 on the complex regulation of cholinergic output is nonetheless not restricted to the visual cortex, but includes additional functions, such as motor learning and associative learning [30,61]. The integrity of the $2-3$ plesiotypic disulfide bond in the LU domain of Lynx1 is essential for its nAChR modulating function $[60,62]$, which is in contrast to observations with CD59, UPAR DI, and $\mathrm{k}$-bungarotoxin where this particular disulfide bond is non-essential for the function of these proteins. One study reports that another GPI-anchored LU-domain protein, LYPD6, also interacts with and modulates nAChR function [63]. A more comprehensive review on the functional aspects of endogenous LU domain modulators of nAChRs is found elsewhere [64].

\subsubsection{GPIHBP1}

From an evolutionary perspective, the inclusion of GPIHBP1 in the LU-domain protein superfamily represents a recent event, as this protein occurs exclusively in the class Mammalia [65]. GPIHBP1 serves an important role in delivering lipids to oxidative tissues such as heart and muscles by focusing active triglyceride hydrolysis to the lumen of capillaries [66]. Several of the essential steps in this complex process are regulated by GPIHBP1: (i) Shuttling of the lipoprotein lipase from the interstitial spaces (where it is secreted by parenchymal cells) to the capillary lumen is exclusively dependent on GPIHBP1 [67]; (ii) margination of triglyceride-rich chylomicrons on the endothelial membrane is mediated by the GPIHBP1 •LPL complex [68]; (iii) extraction of LPL from a dynamic pool, loosely tethered to heparan sulfate proteoglycans, is driven by GPIHBP1 [69]; (iv) stabilization of LPL structure and activity is accomplished by GPIHBP1 binding [70]; and (v) protection from the endogenous protein inhibitors ANGPTL4 and ANGPTL3/8 is also accomplished by GPIHBP1 binding [71]. To perform these roles, GPIHBP1 developed a number of unique properties, which partly were made possible by the addition of an extra exon in front of the exon-set encoding the generic GPI-anchored LU domain 
(Figure 4A). Remarkably, this exon encodes a highly acidic N-terminal extension with 21 negatively charged residues (Glu or Asp) as well as a sulfated tyrosine [69] within 26 consecutive residues in human GPIHBP1 (Figure 4B). The length of this extension is highly variable among mammalian species and can be as long as 50 amino acid residues, including 32 negative charges (Monodelfis domestica; XP_016287565.1). The evolutionary origin of the additional exon-2 in the GPIHBP1 gene remains unclear, but it was speculated to have arisen from integration of a segment of the BCL11A gene [72].

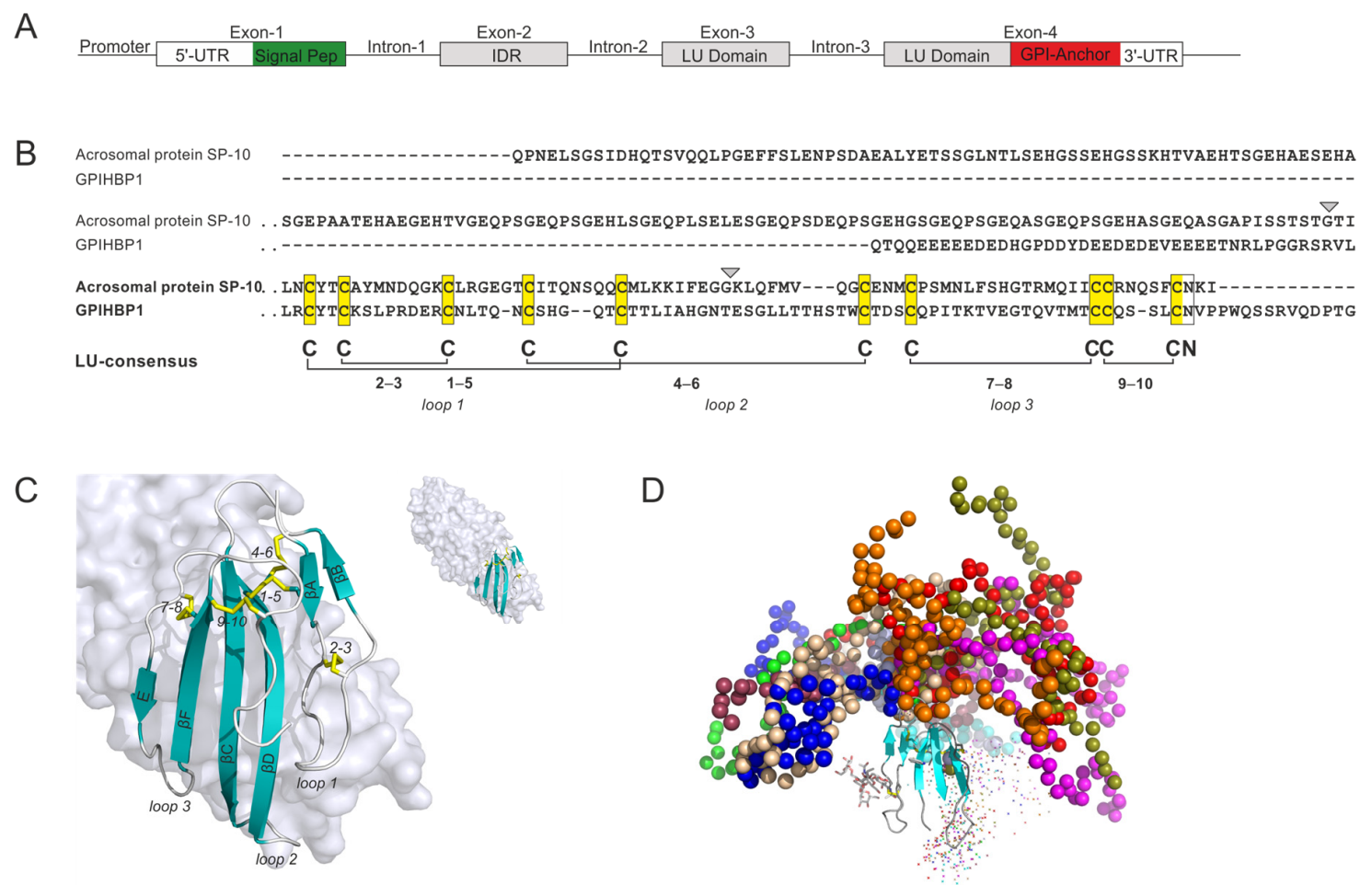

Figure 4. Gene structure, sequence, and three-dimensional structure of GPIHBP1: (A) The gene organization of GPIHBP1, containing an additional exon (IDR) in front of the traditional exon-set encoding the LU domain. (B) A sequence alignment of the LU domains of GPIHBP1 and SP-10, the only two proteins in the human genome with an extra exon encoding an intrinsically disordered $\mathrm{N}$-terminal segment. Gray arrowheads highlight the positions of introns 2 and 3 . The length of the IDR extension of SP-10 varies considerably due to alternative splicing events in exon 2 [73]. (C) The crystal structure of GPIHBP1 bound to the lipoprotein lipase (LPL). The gray surface represents LPL, whereas the LU domain of GPIHBP1 is shown as a cartoon representation, using the same color-coding as in the earlier figures [PDB 6E7K [7]]. Only the LU domain is defined in the crystal structure; as the acidic intrinsically disordered domain at the amino terminus is not well defined in the electron density map and most likely forms a fuzzy complex with LPL. (D) A model of GPIHBP1 based on small-angle X-ray scattering, with the likely spatial distribution of the acidic disordered extension illustrated with colored beads, each color representing one likely spatial distribution. Reproduced with permission from Kristensen et al. [69].

The acidic extension, which is intrinsically disordered, endows GPIHBP1 with several unique functional properties. First, it dramatically increases the encounter rate with LPL due to electrostatic steering; the association rate constant $\left(k_{o n}\right)$ between LPL and GPIHBP1 is thus $>250$-fold greater for full-length GPIHBP1 than for a mutant lacking the acidic N-terminal extension [69]. Second, GPIHBP1's acidic N-terminal extension is crucial for the ability of GPIHBP1 to extract LPL from heparan sulfate proteoglycans in the subendothelial space [69]. Third, GPIHBP1's intrinsically disordered extension has a chaperon-like function, blocking the tendency of LPL to unfold [70]. Finally, GPIHBP1 limits the unfolding of LPL catalyzed by its physiologic inhibitors, the ANGPTL proteins [71]. The entire concave 
face of the central $\beta$-sheet and the three protruding loops of GPIHBP1's LU-domain participate in a hydrophobic binding interface with LPL [7], adding stability to the LPL•GPIHBP1 complex (Figure 4C).

Any defect in the assembly of the LPL•GPIHBP1 complex causes severe hypertriglyceridemia (chylomicronemia) - a condition associated with life-threatening bouts of acute pancreatitis. Chylomicronemia is lifelong in the setting of homozygosity or compound heterozygosity for loss-of-function mutations in GPIHBP1 or LPL [74,75]. Several of these disease-causing missense mutations in human GPIHBP1 involve elimination of one of the plesiotypic cysteine residues in the LU domain (e.g., pCys65Tyr, pCys65Ser, pCys68Tyr, pCys68Gly, pCys83Arg, pCys89Phe), leaving the partner half-cystine with an unpaired thiol-group [74]. In one case, the deleterious mutation actually introduced a new unpaired cysteine in the LU domain of GPIHBP1 (pSer107Cys) [76]. The severe phenotypes of these patients are most likely caused by the destabilizing of the LU-fold leading to multimerization of dysfunctional mutant protein [77].

Acquired forms of chylomicronemia can occasionally occur in children or adults as a result of autoantibodies against GPIHBP1 [78,79]. These autoantibodies, which are directed against the LU domain of GPIHBP1, abolish the ability of GPIHBP1 to bind LPL. Consequently, LPL cannot reach its site of action in the capillary lumen. Approximately one-half of patients with GPIHBP1 autoantibodies have clinical or serologic evidence for autoimmune diseases.

\subsubsection{LY6E}

Two interferon inducible LU genes (LY6E and PSCA) have adverse pathogenic effects, as they enhance the susceptibility of certain cell types to a subset of viral infections. Host entry of Flaviviridae, such as Zika virus, dengue virus, and yellow fever virus, occurs via clathrin-mediated endocytosis, but the size of these virion particles requires the active engagement of a non-canonical endocytosis pathway, which includes the GPI-anchored LU domain protein LY6E [80]. A different mechanism for enhanced viral infection revealed that influenza A rely on $L Y 6 E$ for promoting disassembly of the viral capsid (uncoating) after endosomal escape of the internalized virus. How LY6E aids disassembly of the capsid proteins remains nevertheless unclear, but the base of loop 1 in the LU domain of LY6E seems to play an essential role in this process. Possible mechanistic insights into the LY6E-facilitated entry of viruses may perhaps be gleaned upon from studies on the biological function of LY6E in normal physiology. Ly6e-deficient mice show mid-gestational embryonic lethality (E15.5) due to placental malfunction with impaired labyrinth morphogenesis and imperfect syncytiotrophoblast fusion [81]. This phenotype relates to Ly6e being the endogenous receptor for syncytiotrophoblast layer fusogenic protein A (Syncytin A), which is encoded by Syna, an ancient retroviral envelope gene that was co-opted in Mammalia to mediate fusion of distinct placental cells into functional syncytiotrophoblasts [82].

\subsection{Glycolipid-Anchored Proteins with Multiple LU Domains}

The human genome contains a small locus on chromosome 19q13 that encodes atypical LU domain-containing proteins (LYPD4, CD177, TEX101, LYPD3, PINLYP, PLAUR, LYPD5, SPACA4). Several of these genes encode GPI-anchored proteins with two or more LU domains with the generic intron-exon structure preserved for each added LU domain. As a completely unexpected and unique feature, the $\mathrm{N}$-terminal LU domain in all these multi-LU-domain proteins lack the $7-8$ plesiotypic disulfide bond $[4,83]$. Deleting that particular disulfide bond in the single LU-domain proteins invariably leads to an unstable and aggregated recombinant protein product, implying that this disulfide bond is essential for integrity of a proper folded LU domain $[77,84,85]$. In this section, we will focus on three GPI-anchored proteins from this locus: The urokinase-type plasminogen activator receptor UPAR (PLAUR) with three consecutive LU domains and the two LU domain-containing proteins, C4.4A (LYPD3) and Haldisin (LYDP5).

The best-characterized member of these glycolipid-anchored, multi-LU-domain proteins is the urokinase-type plasminogen activator (uPA) receptor (uPAR), which is also the founding member of the LU domain superfamily. In a functional context, uPAR serves to focus uPA-mediated plasminogen 
activation on the cell surface though high-affinity interaction with the growth factor-like domain of uPA (Figure 5D). One important function of this cell-surface plasminogen activation system is to provide a "clean-up" mechanism for extravascular fibrin. With aging, mice deficient in uPAR show signs of chronic hepatic inflammation due to accumulating fibrin deposition [86], and they also have an impaired neuronal recovery after cerebral ischemia $[87,88]$. Notwithstanding the beneficial function of uPAR, high expression levels of UPAR and uPA may also elicit detrimental pathological effects, particularly in the setting of chronic inflammation. Progression of arthritic lesions seems to be exacerbated by the presence of a high expression levels of uPA and uPAR $[89,90]$. Likewise, numerous studies have demonstrated that high levels of uPAR predict poor survival for patients with solid cancers [91]. These observations have prompted several strategies for uPAR-targeted treatment [92-95]. In addition, they have triggered the development of non-invasive PET-imaging modalities designed to visualize UPAR expression in cancer patients by PET-imaging, with the goal of improved patient stratification [96-98]. Optical imaging of uPAR expression with near-infrared fluorescence is also currently being pursued as an intra-operative tool in guiding precision cancer surgery $[99,100]$.

A

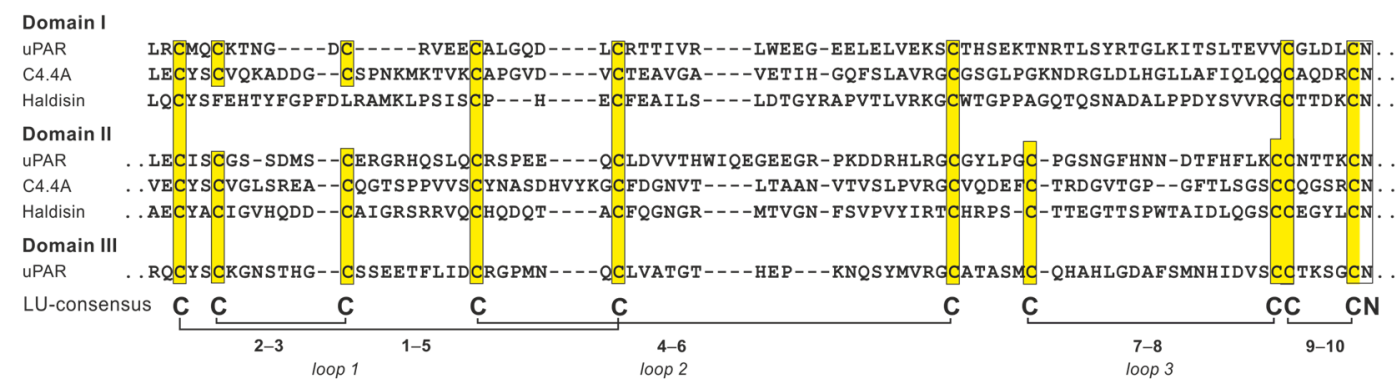

B

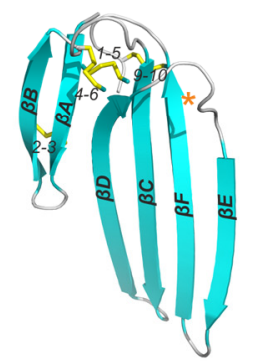

C

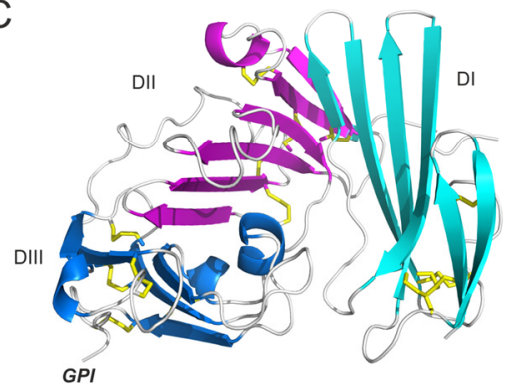

D

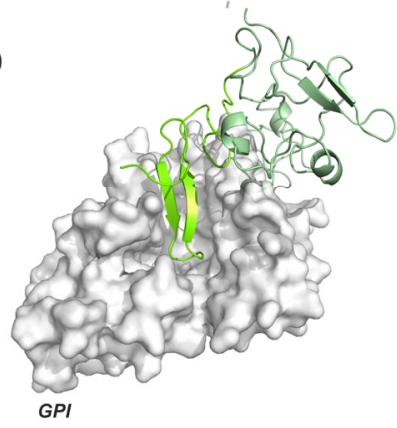

Figure 5. Multi-LU-domain proteins. (A) A sequence alignment of three human multi-LU-domain proteins: uPAR/PLAUR (Uniprot: Q03405), C4.4A/LYPD3 (Uniprot: O95274) and Haldisin/LYPD5 (Unitprot: Q6UWN5). This alignment includes the first two LU domains in uPAR, C4.4A and Haldisin, along with third LU domain in uPAR. Note, that the plesiotypic 7-8 disulfide bond is lacking in all the $\mathrm{N}$-terminal LU domains. (B) Cartoon representation showing that the structure of the N-terminal LU domain of UPAR with the position of the missing 7-8 disulfide highlighted by an asterisk. Disulfide bonds are shown as yellow sticks. (C) Cartoon representation illustrating the assembly of the three LU domains in intact UPAR, with DI in cyan, DII in purple, and DIII in blue. The position of the glycolipid-anchor that tethers uPAR to the cell membrane is shown (GPI). (D) The complex between uPAR (gray surface representation) and the amino-terminal fragment (ATF) of its primary high-affinity ligand uPA (shown in a green cartoon representation). The structures were created by PyMol with the PDB coordinates 3BT1 [101].

The two key physiological binding partners for UPAR, uPA and vitronectin, bind uPAR with markedly different affinities ( $\mathrm{K}_{\mathrm{D}}$ 's for uPA and vitronectin are $0.02 \mathrm{nM}$ and $4 \mu \mathrm{M}$, respectively). A dynamic assembly of all three LU domains in UPAR creates a large hydrophobic uPA-binding cavity involving the concave faces of all of the central $\beta$-sheets of its LU domains [101-106]. Biophysical 
studies have demonstrated that uPAR DI (the first LU domain) is highly flexible and exhibits a dynamic association with DII and DIII, but this inter-domain interface is far more rigid after uPA-binding [106]. This relationship is remarkable, given that uPAR DI lacks the plesiotypic 7-8 disulfide bond, which is indispensable for the folding of single LU-domain proteins. Moreover, this particular disulfide bond stabilizes loop 3 of the LU domain, which is engaged in the interface between uPAR's first and second LU domain (Figure 5C). We therefore propose that some flexibility of this scaffold is needed for the assembly of the LU domains in intact, unoccupied UPAR. Supporting this assumption, we showed that reintroducing the 7-8 disulfide bond into the first LU domain of UPAR impairs uPA binding as well as the dynamic association between DI and DII-DIII in the unoccupied receptor [107]. From an evolutionary perspective, it is noteworthy that all UPAR orthologues identified thus far in Mammalia and Reptilia have three consecutive LU domains, and in each case the N-terminal LU domain lacks the plesiotypic $7-8$ disulfide bond $[107,108]$. The uPAR-like proteins with three consecutive LU domains identified in Sarcopterygii and Amphibia maintain a generic 10-cysteine pattern in each of the three LU domains [108]. However, the uPAR-binding sequences in UPA (as defined within Mammalia) are only present in those species where the 7-8 disulfide bond in the first LU domain of UPAR is absent [107].

Another pair of genes, LYPD3 and LYPD5, located in the same locus as uPAR on chromosome 19q13, encode two GPI-anchored proteins, which are robust biomarkers of epithelial differentiation. C4.4A/LYPD3 is confined to stratum spinosum [109-111], and Haldisin/LYPD5 is confined to stratum granulosum [112]. Both proteins contain two LU domains and the aforementioned 7-8 disulfide bond is absent from their N-terminal LU domain (Figure 5A). In addition, the first LU domain of Haldisin lacks the 2-3 disulfide bond, resulting in a LU domain containing only three of the five plesiotypic disulfide bonds. The biological function of these proteins in the stratified squamous epithelium is unclear, and mice deficient in C4.4A manifest only minor phenotypes [113]. Nonetheless, several independent studies have shown that high levels of C4.4A expression in pulmonary non-small cell adenocarcinomas predicts poor patient survival [114-116].

\subsection{Transmembrane Proteins with a Single Extracellular LU Domain}

It is possible that the LU domain, in an evolutionary context, first appeared as an extracellular ligand-binding domain in the primordial TGF- $\beta$ signaling receptors. These receptors are essential for embryogenesis and ontogenesis of multicellular organisms, and they are already present in primitive bilaterian metazoans with elaborate body plans $[15,117]$. This important class of signaling molecules comprises a large group of agonists, antagonists, anchoring molecules (e.g., latent TGF- $\beta$ binding protein), signaling receptors (type I and type II), and co-receptors [117]. The co-evolution, protein structures, and molecular mechanisms defining this system have been thoroughly investigated. A more detailed description can be found in a comprehensive and contemporary review by Hinck et al. [117]. A central event in this signaling pathway is driven by the heterodimerization of two integral membrane receptors by ligand binding to their extracellular domains (ECD). The ECD of type I receptors (e.g., TGF- $\beta$ R1, BMPR1A, and ACVR1A) all comply with the plesiotypic LU domain signature with 10 cysteines and the stereotypic disulfide bonding pattern (Figure 6A). In contrast, ECDs of type II receptors have a more divergent cysteine pattern and a longer loop 1. In BMPR2 and ACVR2, the ECD has lost the 2-3 disulfide bond and gained another apotypic disulfide bond tethering strand $\mathrm{E}$ to the back of the three-fingered scaffold (Figure 6C). This cysteine configuration resembles the one found in LYPD6, where an apotypic disulfide bond also stabilizes loop 3, albeit at a more distal position (Figure $6 \mathrm{D}$ ). The ECD of TGF- $\beta$ R2 represents the most divergent member of this family. This domain has lost the 7-8 plesiotypic disulfide bond, but gained two additional apotypic disulfide bonds stabilizing loop 1 and loop 3 (Figure 6). 
A

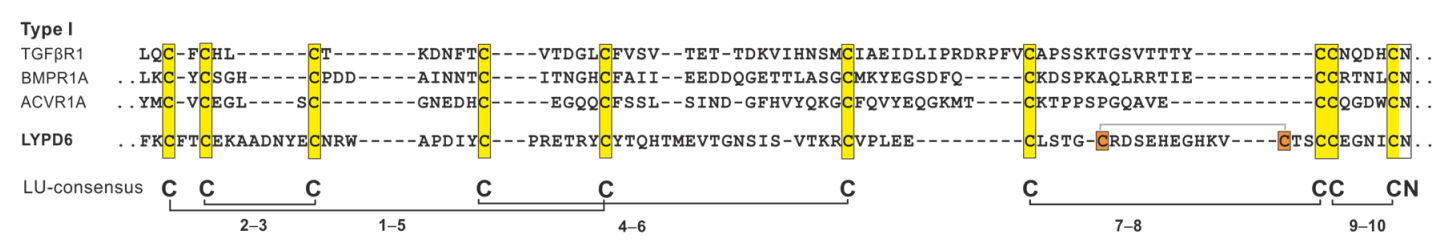

TGFBR2 . QICKFCDVRFSTCDNQKSCMSNCSITSIC---EKPQEVCVAVW--RKND-ENITLETVCHDPKLPYHDFILEDAASPK-CIMREKKKPGETFFM--CSOSSDECN .

BMPR2 -.RLCAFKDPYQQDLGIGESRISHENGTILC----SKGSTCYGLW--EKSKGDINLVKQGCWSHIGDPQE-----CHYEE-CVVTTTPPSIQNGTYRFCCOSTDICN.

ACVR2A . QECLIFFN-ANWEKD-----RTNQTGVEPCYGDKDKRRHCFATW--KNISGSIEIVKQGCWLDDIN--------CYDRTDCVEKKDSPEVYF-----CCCEGNMCN.

LU-consensus $\mathbf{C}$

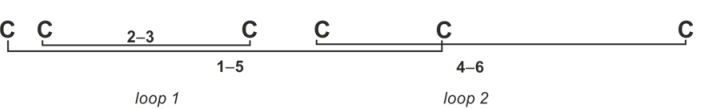

B

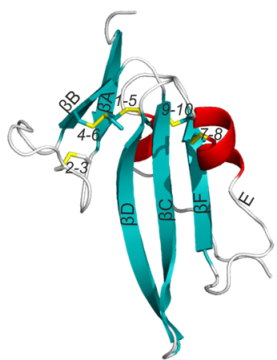

BMPR1A
C

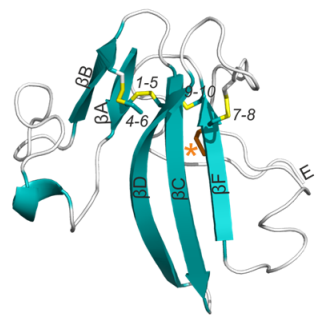

BMPR2
C

$\begin{aligned} & 7-8 \\ & 10003\end{aligned} \quad 9-10$

$\mathrm{D}$

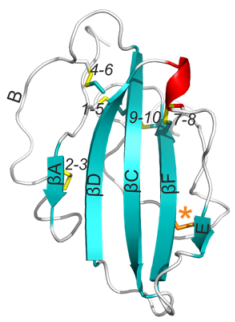

LYPD6

Figure 6. Integral membrane receptors in which the LU domains function as extracellular ligand-binding domains. (A) A sequence alignment of the extracellular N-terminal ligand-binding LU domain of the TGF- $\beta$ receptor 1 (Uniprot: P36897), bone morphogenetic protein receptor $1 \mathrm{~A}$ (Uniprot: P36894), activing receptor 1A (Uniprot: Q04771), LYPD6 (Uniprot: Q86478), TGF- $\beta$ receptor 2 (Uniprot: P37173), bone morphogenetic protein receptor 2 (Uniprot: Q13873), and activin receptor 2 (Uniprot: P27037). The separation of the alignment for type 1 and type 2 receptors emphasizes the preservation of the LU signature in type 1 receptors and the introduction of apotypic disulfide bonds in the type 2 receptors (highlighted by orange boxes). Representative structures of (B) bone morphogenetic protein receptor 1A [PDB: 1REW [118]]; (C) bone morphogenetic protein receptor 2 [PDB: 2HLQ [119]]; and (D) LYPD6 (PDB: 6GBI [120]). Orange asterisks mark positions of the apotypic disulfide bonds.

\section{Conclusions}

The LU domain is widespread in the Metazoa kingdom, where it carries out an extremely diverse set of biological functions. Although this domain is encoded by an exon-set with symmetrical intron-exon boundaries (mostly of phase 1), it probably cannot be considered a bona fide mobile protein module, as it is found predominantly as single LU-domain proteins or as repetitive units in multidomain proteins containing only this domain. However, it would be entirely reasonable to propose the LU domain as a "proto-module", given that it is found in the context of a non-homologous protein environment in a few proteins, for example, GPIHBP1, SP-10 and the ECD of TGF- $\beta$ receptors.

Author Contributions: J.M.L., M.P.; writing—original draft preparation, J.M.L., K.Z.L.-E., K.K.K., A.K., A.-M.L.W., S.G.Y. and M.P.; writing-review and editing, J.M.L.; visualization.

Funding: This research received no external funding.

Conflicts of Interest: The authors declare no conflict of interest. 


\section{Abbreviations}

$\begin{array}{ll}\text { ECD } & \text { Extracellular domain } \\ \text { GPIHBP1 } & \text { Glycosylphosphatidylinositol-anchored high density lipoprotein-binding protein } 1 \\ \text { HSPG } & \text { Heparan sulfate proteoglycan } \\ \text { LU } & \text { Ly6/uPAR type } \\ \text { uPAR } & \text { Urokinase-type Plasminogen Activator Receptor } \\ \text { SLURP1 } & \text { Secreted Ly6/uPAR related protein } 1\end{array}$

\section{References}

1. Tordai, H.; Nagy, A.; Farkas, K.; Banyai, L.; Patthy, L. Modules, multidomain proteins and organismic complexity. FEBS J. 2005, 272, 5064-5078. [CrossRef] [PubMed]

2. Campbell, I.D. Modular proteins at the cell surface. Biochem. Soc. Trans. 2003, 31, 1107-1114. [CrossRef] [PubMed]

3. Loughner, C.L.; Bruford, E.A.; McAndrews, M.S.; Delp, E.E.; Swamynathan, S.; Swamynathan, S.K. Organization, evolution and functions of the human and mouse Ly6/uPAR family genes. Hum. Genom. 2016, 10, 10. [CrossRef] [PubMed]

4. Kjaergaard, M.; Hansen, L.V.; Jacobsen, B.; Gardsvoll, H.; Ploug, M. Structure and ligand interactions of the urokinase receptor (uPAR). Front. Biosci. 2008, 13, 5441-5461. [CrossRef] [PubMed]

5. Tanaka, K.; Diekmann, Y.; Hazbun, A.; Hijazi, A.; Vreede, B.; Roch, F.; Sucena, E. Multispecies Analysis of Expression Pattern Diversification in the Recently Expanded Insect Ly6 Gene Family. Mol. Biol. Evol. 2015, 32, 1730-1747. [CrossRef]

6. Sunagar, K.; Jackson, T.N.; Undheim, E.A.; Ali, S.A.; Antunes, A.; Fry, B.G. Three-fingered RAVERs: Rapid Accumulation of Variations in Exposed Residues of snake venom toxins. Toxins 2013, 5, 2172-2208. [CrossRef] [PubMed]

7. Birrane, G.; Beigneux, A.P.; Dwyer, B.; Strack-Logue, B.; Kristensen, K.K.; Francone, O.L.; Fong, L.G.; Mertens, H.D.T.; Pan, C.Q.; Ploug, M.; et al. Structure of the lipoprotein lipase-GPIHBP1 complex that mediates plasma triglyceride hydrolysis. Proc. Natl. Acad. Sci. USA 2019, 116, 1723-1732. [CrossRef]

8. Kessler, P.; Marchot, P.; Silva, M.; Servent, D. The three-finger toxin fold: A multifunctional structural scaffold able to modulate cholinergic functions. J. Neurochem. 2017, 142 Suppl. 2, 7-18. [CrossRef]

9. Sun, D.; Yu, Y.; Xue, X.; Pan, M.; Wen, M.; Li, S.; Qu, Q.; Li, X.; Zhang, L.; Li, X.; et al. Cryo-EM structure of the ASIC1a-mambalgin-1 complex reveals that the peptide toxin mambalgin-1 inhibits acid-sensing ion channels through an unusual allosteric effect. Cell Discov. 2018, 4, 27. [CrossRef]

10. Townson, S.A.; Martinez-Hackert, E.; Greppi, C.; Lowden, P.; Sako, D.; Liu, J.; Ucran, J.A.; Liharska, K.; Underwood, K.W.; Seehra, J.; et al. Specificity and structure of a high affinity activin receptor-like kinase 1 (ALK1) signaling complex. J. Biol. Chem. 2012, 287, 27313-27325. [CrossRef]

11. Chalmers, I.W.; Fitzsimmons, C.M.; Brown, M.; Pierrot, C.; Jones, F.M.; Wawrzyniak, J.M.; Fernandez-Fuentes, N.; Tukahebwa, E.M.; Dunne, D.W.; Khalife, J.; et al. Human IgG1 Responses to Surface Localised Schistosoma mansoni Ly6 Family Members Drop following Praziquantel Treatment. PLoS Negl. Trop. Dis. 2015, 9, e0003920. [CrossRef] [PubMed]

12. Huang, Y.; Fedarovich, A.; Tomlinson, S.; Davies, C. Crystal structure of CD59: Implications for molecular recognition of the complement proteins C8 and C9 in the membrane-attack complex. Acta Crystallogr. D Biol. Crystallogr. 2007, 63, 714-721. [CrossRef] [PubMed]

13. Lyukmanova, E.N.; Shenkarev, Z.O.; Shulepko, M.A.; Mineev, K.S.; D’Hoedt, D.; Kasheverov, I.E.; Filkin, S.Y.; Krivolapova, A.P.; Janickova, H.; Dolezal, V.; et al. NMR structure and action on nicotinic acetylcholine receptors of water-soluble domain of human LYNX1. J. Biol. Chem. 2011, 286, 10618-10627. [CrossRef] [PubMed]

14. Kuhn, P.; Deacon, A.M.; Comoso, S.; Rajaseger, G.; Kini, R.M.; Uson, I.; Kolatkar, P.R. The atomic resolution structure of bucandin, a novel toxin isolated from the Malayan krait, determined by direct methods. Acta Crystallogr. D Biol. Crystallogr. 2000, 56, 1401-1407. [CrossRef] [PubMed]

15. Galat, A. Multidimensional Drift of Sequence Attributes and Functional Profiles in the Superfamily of the Three-Finger Proteins and Their Structural Homologues. J. Chem. Inf. Model. 2015, 55, 2026-2041. [CrossRef] [PubMed] 
16. Shabelnikov, S.V.; Bobkov, D.E.; Sharlaimova, N.S.; Petukhova, O.A. Injury affects coelomic fluid proteome of the common starfish, Asterias rubens. J. Exp. Biol. 2019, 222, jeb198556. [CrossRef] [PubMed]

17. Pawlak, J.; Mackessy, S.P.; Sixberry, N.M.; Stura, E.A.; Le Du, M.H.; Menez, R.; Foo, C.S.; Menez, A.; Nirthanan, S.; Kini, R.M. Irditoxin, a novel covalently linked heterodimeric three-finger toxin with high taxon-specific neurotoxicity. FASEB J. 2009, 23, 534-545. [CrossRef]

18. Wong, J.W.; Ho, S.Y.; Hogg, P.J. Disulfide bond acquisition through eukaryotic protein evolution. Mol. Biol. Evol. 2011, 28, 327-334. [CrossRef]

19. Dashevsky, D.; Debono, J.; Rokyta, D.; Nouwens, A.; Josh, P.; Fry, B.G. Three-Finger Toxin Diversification in the Venoms of Cat-Eye Snakes (Colubridae: Boiga). J. Mol. Evol. 2018. [CrossRef]

20. Roy, A.; Zhou, X.; Chong, M.Z.; D’Hoedt, D.; Foo, C.S.; Rajagopalan, N.; Nirthanan, S.; Bertrand, D.; Sivaraman, J.; Kini, R.M. Structural and functional characterization of a novel homodimeric three-finger neurotoxin from the venom of Ophiophagus hannah (king cobra). J. Biol. Chem. 2010, 285, 8302-8315. [CrossRef]

21. Diochot, S.; Baron, A.; Salinas, M.; Douguet, D.; Scarzello, S.; Dabert-Gay, A.S.; Debayle, D.; Friend, V.; Alloui, A.; Lazdunski, M.; et al. Black mamba venom peptides target acid-sensing ion channels to abolish pain. Nature 2012, 490, 552-555. [CrossRef] [PubMed]

22. Pawlak, J.; Mackessy, S.P.; Fry, B.G.; Bhatia, M.; Mourier, G.; Fruchart-Gaillard, C.; Servent, D.; Menez, R.; Stura, E.; Menez, A.; et al. Denmotoxin, a three-finger toxin from the colubrid snake Boiga dendrophila (Mangrove Catsnake) with bird-specific activity. J. Biol. Chem. 2006, 281, 29030-29041. [CrossRef] [PubMed]

23. Cheng, C.H.; Chen, Y.C.; Shiu, J.H.; Chang, Y.T.; Chang, Y.S.; Huang, C.H.; Chen, C.Y.; Chuang, W.J. Dynamics and functional differences between dendroaspin and rhodostomin: Insights into protein scaffolds in integrin recognition. Protein Sci. 2012, 21, 1872-1884. [CrossRef] [PubMed]

24. Harel, M.; Kasher, R.; Nicolas, A.; Guss, J.M.; Balass, M.; Fridkin, M.; Smit, A.B.; Brejc, K.; Sixma, T.K.; Katchalski-Katzir, E.; et al. The binding site of acetylcholine receptor as visualized in the X-Ray structure of a complex between alpha-bungarotoxin and a mimotope peptide. Neuron 2001, 32, 265-275. [CrossRef]

25. Dewan, J.C.; Grant, G.A.; Sacchettini, J.C. Crystal Structure of.kappa.-Bungarotoxin at 2.3-.ANG. Resolution. Biochemistry 1994, 33, 13147-13154. [CrossRef]

26. Fry, B.G. From genome to "venome": Molecular origin and evolution of the snake venom proteome inferred from phylogenetic analysis of toxin sequences and related body proteins. Genome Res. 2005, 15, 403-420. [CrossRef]

27. Casewell, N.R.; Huttley, G.A.; Wuster, W. Dynamic evolution of venom proteins in squamate reptiles. Nat. Commun 2012, 3, 1066. [CrossRef]

28. Vonk, F.J.; Casewell, N.R.; Henkel, C.V.; Heimberg, A.M.; Jansen, H.J.; McCleary, R.J.; Kerkkamp, H.M.; Vos, R.A.; Guerreiro, I.; Calvete, J.J.; et al. The king cobra genome reveals dynamic gene evolution and adaptation in the snake venom system. Proc. Natl. Acad. Sci. USA 2013, 110, 20651-20656. [CrossRef]

29. Morishita, H.; Miwa, J.M.; Heintz, N.; Hensch, T.K. Lynx1, a cholinergic brake, limits plasticity in adult visual cortex. Science 2010, 330, 1238-1240. [CrossRef]

30. Miwa, J.M.; Stevens, T.R.; King, S.L.; Caldarone, B.J.; Ibanez-Tallon, I.; Xiao, C.; Fitzsimonds, R.M.; Pavlides, C.; Lester, H.A.; Picciotto, M.R.; et al. The prototoxin lynx1 acts on nicotinic acetylcholine receptors to balance neuronal activity and survival in vivo. Neuron 2006, 51,587-600. [CrossRef]

31. Lyukmanova, E.N.; Shulepko, M.A.; Kudryavtsev, D.; Bychkov, M.L.; Kulbatskii, D.S.; Kasheverov, I.E.; Astapova, M.V.; Feofanov, A.V.; Thomsen, M.S.; Mikkelsen, J.D.; et al. Human Secreted Ly-6/uPAR Related Protein-1 (SLURP-1) Is a Selective Allosteric Antagonist of alpha7 Nicotinic Acetylcholine Receptor. PLoS ONE 2016, 11, e0149733. [CrossRef] [PubMed]

32. Ibanez-Tallon, I.; Wen, H.; Miwa, J.M.; Xing, J.; Tekinay, A.B.; Ono, F.; Brehm, P.; Heintz, N. Tethering naturally occurring peptide toxins for cell-autonomous modulation of ion channels and receptors in vivo. Neuron 2004, 43, 305-311. [CrossRef] [PubMed]

33. Hijazi, A.; Masson, W.; Auge, B.; Waltzer, L.; Haenlin, M.; Roch, F. Boudin is required for septate junction organisation in Drosophila and codes for a diffusible protein of the Ly6 superfamily. Development 2009, 136, 2199-2209. [CrossRef] [PubMed]

34. Baudouin-Gonzalez, L.; Santos, M.A.; Tempesta, C.; Sucena, E.; Roch, F.; Tanaka, K. Diverse Cis-Regulatory Mechanisms Contribute to Expression Evolution of Tandem Gene Duplicates. Mol. Biol. Evol. 2017, 34, 3132-3147. [CrossRef] [PubMed] 
35. Nilton, A.; Oshima, K.; Zare, F.; Byri, S.; Nannmark, U.; Nyberg, K.G.; Fehon, R.G.; Uv, A.E. Crooked, coiled and crimpled are three Ly6-like proteins required for proper localization of septate junction components. Development 2010, 137, 2427-2437. [CrossRef] [PubMed]

36. Tempesta, C.; Hijazi, A.; Moussian, B.; Roch, F. Boudin trafficking reveals the dynamic internalisation of specific septate junction components in Drosophila. PLoS ONE 2017, 12, e0185897. [CrossRef] [PubMed]

37. Shi, M.; Yue, Z.; Kuryatov, A.; Lindstrom, J.M.; Sehgal, A. Identification of Redeye, a new sleep-regulating protein whose expression is modulated by sleep amount. eLife 2014, 3, e01473. [CrossRef]

38. Wu, M.N.; Joiner, W.J.; Dean, T.; Yue, Z.; Smith, C.J.; Chen, D.; Hoshi, T.; Sehgal, A.; Koh, K. SLEEPLESS, a Ly-6/neurotoxin family member, regulates the levels, localization and activity of Shaker. Nat. Neurosci. 2010, 13, 69-75. [CrossRef]

39. Wu, M.; Robinson, J.E.; Joiner, W.J. SLEEPLESS is a bifunctional regulator of excitability and cholinergic synaptic transmission. Curr. Biol. 2014, 24, 621-629. [CrossRef]

40. Fujihara, Y.; Tokuhiro, K.; Muro, Y.; Kondoh, G.; Araki, Y.; Ikawa, M.; Okabe, M. Expression of TEX101, regulated by ACE, is essential for the production of fertile mouse spermatozoa. Proc. Natl. Acad. Sci. USA 2013, 110, 8111-8116. [CrossRef]

41. Herberg, S.; Gert, K.R.; Schleiffer, A.; Pauli, A. The Ly6/uPAR protein Bouncer is necessary and sufficient for species-specific fertilization. Science 2018, 361, 1029-1033. [CrossRef] [PubMed]

42. Guo, Q.; Ji, D.; Wang, M.; Zhang, S.; Li, H. Identification and expression of an uncharacterized Ly-6 gene cluster in zebrafish Danio rerio. Funct. Integr. Genom. 2015, 15, 577-585. [CrossRef] [PubMed]

43. Ji, D.; Wang, S.; Li, M.; Zhang, S.; Li, H. Involvement of Lypge in the formation of eye and pineal gland in zebrafish. Gene 2018, 642, 491-497. [CrossRef] [PubMed]

44. Ji, D.; Liu, P.; Wang, F.; Zhang, S.; Li, H. Identification and expression of a novel member of Ly-6 superfamily in zebrafish Denio rerio. Dev. Genes Evol. 2012, 222, 119-124. [CrossRef] [PubMed]

45. Ozhan, G.; Sezgin, E.; Wehner, D.; Pfister, A.S.; Kuhl, S.J.; Kagermeier-Schenk, B.; Kuhl, M.; Schwille, P.; Weidinger, G. Lypd6 enhances Wnt/beta-catenin signaling by promoting Lrp6 phosphorylation in raft plasma membrane domains. Dev. Cell 2013, 26, 331-345. [CrossRef]

46. Perez, C.; Khachemoune, A. Mal de Meleda: A Focused Review. Am. J. Clin. Dermatol. 2016, 17, 63-70. [CrossRef] [PubMed]

47. Favre, B.; Plantard, L.; Aeschbach, L.; Brakch, N.; Christen-Zaech, S.; de Viragh, P.A.; Sergeant, A.; Huber, M.; Hohl, D. SLURP1 is a late marker of epidermal differentiation and is absent in Mal de Meleda. J. Investig. Dermatol. 2007, 127, 301-308. [CrossRef]

48. Adeyo, O.; Oberer, M.; Ploug, M.; Fong, L.G.; Young, S.G.; Beigneux, A.P. Heterogeneity in the properties of mutant secreted lymphocyte antigen 6/urokinase receptor-related protein 1 (SLURP1) in Mal de Meleda. Br. J. Dermatol. 2015, 173, 1066-1069. [CrossRef]

49. Adeyo, O.; Allan, B.B.; Barnes, R.H., 2nd; Goulbourne, C.N.; Tatar, A.; Tu, Y.; Young, L.C.; Weinstein, M.M.; Tontonoz, P.; Fong, L.G.; et al. Palmoplantar keratoderma along with neuromuscular and metabolic phenotypes in Slurp1-deficient mice. J. Investig. Dermatol. 2014, 134, 1589-1598. [CrossRef]

50. Allan, C.M.; Procaccia, S.; Tran, D.; Tu, Y.; Barnes, R.H., 2nd; Larsson, M.; Allan, B.B.; Young, L.C.; Hong, C.; Tontonoz, P.; et al. Palmoplantar Keratoderma in Slurp2-Deficient Mice. J. Investig. Dermatol. 2016, 136, 436-443. [CrossRef]

51. Allan, C.M.; Heizer, P.J.; Jung, C.J.; Tu, Y.; Tran, D.; Young, L.C.; Fong, L.G.; de Jong, P.J.; Beigneux, A.P.; Young, S.G. Palmoplantar keratoderma in Slurp1/Slurp2 double-knockout mice. J. Dermatol. Sci. 2018, 89, 85-87. [CrossRef] [PubMed]

52. Lyukmanova, E.N.; Shulepko, M.A.; Shenkarev, Z.O.; Bychkov, M.L.; Paramonov, A.S.; Chugunov, A.O.; Kulbatskii, D.S.; Arvaniti, M.; Dolejsi, E.; Schaer, T.; et al. Secreted Isoform of Human Lynx1 (SLURP-2): Spatial Structure and Pharmacology of Interactions with Different Types of Acetylcholine Receptors. Sci. Rep. 2016, 6, 30698. [CrossRef] [PubMed]

53. Boshra, H.; Zelek, W.M.; Hughes, T.R.; Rodriguez de Cordoba, S.; Morgan, B.P. Absence of CD59 in Guinea Pigs: Analysis of the Cavia porcellus Genome Suggests the Evolution of a CD59 Pseudogene. J. Immunol. 2018, 200, 327-335. [CrossRef] [PubMed]

54. Nevo, Y.; Ben-Zeev, B.; Tabib, A.; Straussberg, R.; Anikster, Y.; Shorer, Z.; Fattal-Valevski, A.; Ta-Shma, A.; Aharoni, S.; Rabie, M.; et al. CD59 deficiency is associated with chronic hemolysis and childhood relapsing immune-mediated polyneuropathy. Blood 2013, 121, 129-135. [CrossRef] [PubMed] 
55. Kinoshita, T. Congenital Defects in the Expression of the Glycosylphosphatidylinositol-Anchored Complement Regulatory Proteins CD59 and Decay-Accelerating Factor. Semin. Hematol. 2018, 55, 136-140. [CrossRef] [PubMed]

56. Tabib, A.; Hindi, I.; Karbian, N.; Zelig, O.; Falach, B.; Mevorach, D. Prothrombotic mechanisms in patients with congenital p.Cys89Tyr mutation in CD59. Thromb. Res. 2018, 168, 67-77. [CrossRef] [PubMed]

57. Karbian, N.; Eshed-Eisenbach, Y.; Tabib, A.; Hoizman, H.; Morgan, B.P.; Schueler-Furman, O.; Peles, E.; Mevorach, D. Molecular pathogenesis of human CD59 deficiency. Neurol. Genet. 2018, 4, e280. [CrossRef]

58. Miwa, T.; Zhou, L.; Hilliard, B.; Molina, H.; Song, W.C. Crry, but not CD59 and DAF, is indispensable for murine erythrocyte protection in vivo from spontaneous complement attack. Blood 2002, 99, 3707-3716. [CrossRef]

59. Miwa, J.M.; Ibanez-Tallon, I.; Crabtree, G.W.; Sanchez, R.; Sali, A.; Role, L.W.; Heintz, N. lynx1, an endogenous toxin-like modulator of nicotinic acetylcholine receptors in the mammalian CNS. Neuron 1999, 23, 105-114. [CrossRef]

60. Ibanez-Tallon, I.; Miwa, J.M.; Wang, H.L.; Adams, N.C.; Crabtree, G.W.; Sine, S.M.; Heintz, N. Novel modulation of neuronal nicotinic acetylcholine receptors by association with the endogenous prototoxin lynx1. Neuron 2002, 33, 893-903. [CrossRef]

61. Miwa, J.M.; Walz, A. Enhancement in motor learning through genetic manipulation of the Lynx1 gene. PLoS ONE 2012, 7, e43302. [CrossRef]

62. George, A.A.; Bloy, A.; Miwa, J.M.; Lindstrom, J.M.; Lukas, R.J.; Whiteaker, P. Isoform-specific mechanisms of alpha3beta4*-nicotinic acetylcholine receptor modulation by the prototoxin lynx1. FASEB J. 2017, 31, 1398-1420. [CrossRef] [PubMed]

63. Arvaniti, M.; Jensen, M.M.; Soni, N.; Wang, H.; Klein, A.B.; Thiriet, N.; Pinborg, L.H.; Muldoon, P.P.; Wienecke, J.; Imad Damaj, M.; et al. Functional interaction between Lypd6 and nicotinic acetylcholine receptors. J. Neurochem. 2016, 138, 806-820. [CrossRef] [PubMed]

64. Tsetlin, V.I. Three-finger snake neurotoxins and Ly6 proteins targeting nicotinic acetylcholine receptors: Pharmacological tools and endogenous modulators. Trends Pharmacol. Sci. 2015, 36, 109-123. [CrossRef] [PubMed]

65. He, C.; Hu, X.; Jung, R.S.; Larsson, M.; Tu, Y.; Duarte-Vogel, S.; Kim, P.; Sandoval, N.P.; Price, T.R.; Allan, C.M.; et al. Lipoprotein lipase reaches the capillary lumen in chickens despite an apparent absence of GPIHBP1. JCI Insight 2017, 2. [CrossRef] [PubMed]

66. Fong, L.G.; Young, S.G.; Beigneux, A.P.; Bensadoun, A.; Oberer, M.; Jiang, H.; Ploug, M. GPIHBP1 and Plasma Triglyceride Metabolism. Trends Endocrinol. Metab. 2016, 27, 455-469. [CrossRef] [PubMed]

67. Davies, B.S.; Beigneux, A.P.; Barnes, R.H., 2nd; Tu, Y.; Gin, P.; Weinstein, M.M.; Nobumori, C.; Nyren, R.; Goldberg, I.; Olivecrona, G.; et al. GPIHBP1 is responsible for the entry of lipoprotein lipase into capillaries. Cell Metab. 2010, 12, 42-52. [CrossRef]

68. Goulbourne, C.N.; Gin, P.; Tatar, A.; Nobumori, C.; Hoenger, A.; Jiang, H.; Grovenor, C.R.; Adeyo, O.; Esko, J.D.; Goldberg, I.J.; et al. The GPIHBP1-LPL complex is responsible for the margination of triglyceride-rich lipoproteins in capillaries. Cell Metab. 2014, 19, 849-860. [CrossRef]

69. Kristensen, K.K.; Midtgaard, S.R.; Mysling, S.; Kovrov, O.; Hansen, L.B.; Skar-Gislinge, N.; Beigneux, A.P.; Kragelund, B.B.; Olivecrona, G.; Young, S.G.; et al. A disordered acidic domain in GPIHBP1 harboring a sulfated tyrosine regulates lipoprotein lipase. Proc. Natl. Acad. Sci. USA 2018, 115, E6020-E6029. [CrossRef]

70. Mysling, S.; Kristensen, K.K.; Larsson, M.; Beigneux, A.P.; Gardsvoll, H.; Fong, L.G.; Bensadouen, A.; Jorgensen, T.J.; Young, S.G.; Ploug, M. The acidic domain of the endothelial membrane protein GPIHBP1 stabilizes lipoprotein lipase activity by preventing unfolding of its catalytic domain. eLife 2016, 5, e12095. [CrossRef]

71. Mysling, S.; Kristensen, K.K.; Larsson, M.; Kovrov, O.; Bensadouen, A.; Jorgensen, T.J.; Olivecrona, G.; Young, S.G.; Ploug, M. The angiopoietin-like protein ANGPTL4 catalyzes unfolding of the hydrolase domain in lipoprotein lipase and the endothelial membrane protein GPIHBP1 counteracts this unfolding. eLife 2016, 5. [CrossRef]

72. Holmes, R.S.; Cox, L.A. Comparative studies of glycosylphosphatidylinositol-anchored high-density lipoprotein-binding protein 1: Evidence for a eutherian mammalian origin for the GPIHBP1 gene from an LY6-like gene. 3 Biotech 2012, 2, 37-52. [CrossRef] [PubMed] 
73. Freemerman, A.J.; Flickinger, C.J.; Herr, J.C. Characterization of alternatively spliced human SP-10 mRNAs. Mol. Reprod. Dev. 1995, 41, 100-108. [CrossRef] [PubMed]

74. Rabacchi, C.; D'Addato, S.; Palmisano, S.; Lucchi, T.; Bertolini, S.; Calandra, S.; Tarugi, P. Clinical and genetic features of 3 patients with familial chylomicronemia due to mutations in GPIHBP1 gene. J. Clin. Lipidol. 2016, 10, 915-921.e914. [CrossRef] [PubMed]

75. Rodrigues, R.; Artieda, M.; Tejedor, D.; Martinez, A.; Konstantinova, P.; Petry, H.; Meyer, C.; Corzo, D.; Sundgreen, C.; Klor, H.U.; et al. Pathogenic classification of LPL gene variants reported to be associated with LPL deficiency. J. Clin. Lipidol. 2016, 10, 394-409. [CrossRef] [PubMed]

76. Plengpanich, W.; Young, S.G.; Khovidhunkit, W.; Bensadoun, A.; Karnman, H.; Ploug, M.; Gardsvoll, H.; Leung, C.S.; Adeyo, O.; Larsson, M.; et al. Multimerization of glycosylphosphatidylinositol-anchored high density lipoprotein-binding protein 1 (GPIHBP1) and familial chylomicronemia from a serine-to-cysteine substitution in GPIHBP1 Ly6 domain. J. Biol. Chem. 2014, 289, 19491-19499. [CrossRef] [PubMed]

77. Beigneux, A.P.; Fong, L.G.; Bensadoun, A.; Davies, B.S.; Oberer, M.; Gardsvoll, H.; Ploug, M.; Young, S.G. GPIHBP1 missense mutations often cause multimerization of GPIHBP1 and thereby prevent lipoprotein lipase binding. Circ. Res. 2015, 116, 624-632. [CrossRef]

78. Beigneux, A.P.; Miyashita, K.; Ploug, M.; Blom, D.J.; Ai, M.; Linton, M.F.; Khovidhunkit, W.; Dufour, R.; Garg, A.; McMahon, M.A.; et al. Autoantibodies against GPIHBP1 as a Cause of Hypertriglyceridemia. N. Engl. J. Med. 2017, 376, 1647-1658. [CrossRef]

79. Hu, X.; Dallinga-Thie, G.M.; Hovingh, G.K.; Chang, S.Y.; Sandoval, N.P.; Dang, T.L.P.; Fukamachi, I.; Miyashita, K.; Nakajima, K.; Murakami, M.; et al. GPIHBP1 autoantibodies in a patient with unexplained chylomicronemia. J. Clin. Lipidol 2017, 11, 964-971. [CrossRef]

80. Hackett, B.A.; Cherry, S. Flavivirus internalization is regulated by a size-dependent endocytic pathway. Proc. Natl. Acad. Sci. USA 2018, 115, 4246-4251. [CrossRef]

81. Langford, M.B.; Outhwaite, J.E.; Hughes, M.; Natale, D.R.C.; Simmons, D.G. Deletion of the Syncytin A receptor Ly6e impairs syncytiotrophoblast fusion and placental morphogenesis causing embryonic lethality in mice. Sci. Rep. 2018, 8, 3961. [CrossRef]

82. Bacquin, A.; Bireau, C.; Tanguy, M.; Romanet, C.; Vernochet, C.; Dupressoir, A.; Heidmann, T. A Cell Fusion-Based Screening Method Identifies Glycosylphosphatidylinositol-Anchored Protein Ly6e as the Receptor for Mouse Endogenous Retroviral Envelope Syncytin-A. J. Virol. 2017, 91. [CrossRef]

83. Ploug, M. Structure-function relationships in the interaction between the urokinase-type plasminogen activator and its receptor. Curr. Pharm. Des. 2003, 9, 1499-1528. [CrossRef] [PubMed]

84. Petranka, J.; Zhao, J.; Norris, J.; Tweedy, N.B.; Ware, R.E.; Sims, P.J.; Rosse, W.F. Structure-function relationships of the complement regulatory protein, CD59. Blood Cells Mol. Dis. 1996, 22, 281-296. [CrossRef] [PubMed]

85. Grant, G.A.; Luetje, C.W.; Summers, R.; Xu, X.L. Differential roles for disulfide bonds in the structural integrity and biological activity of kappa-Bungarotoxin, a neuronal nicotinic acetylcholine receptor antagonist. Biochemistry 1998, 37, 12166-12171. [CrossRef] [PubMed]

86. Connolly, B.M.; Choi, E.Y.; Gardsvoll, H.; Bey, A.L.; Currie, B.M.; Chavakis, T.; Liu, S.; Molinolo, A.; Ploug, M.; Leppla, S.H.; et al. Selective abrogation of the uPA-uPAR interaction in vivo reveals a novel role in suppression of fibrin-associated inflammation. Blood 2010, 116, 1593-1603. [CrossRef] [PubMed]

87. Diaz, A.; Merino, P.; Manrique, L.G.; Ospina, J.P.; Cheng, L.; Wu, F.; Jeanneret, V.; Yepes, M. A Cross Talk between Neuronal Urokinase-type Plasminogen Activator (uPA) and Astrocytic uPA Receptor (uPAR) Promotes Astrocytic Activation and Synaptic Recovery in the Ischemic Brain. J. Neurosci. 2017, 37, 10310-10322. [CrossRef] [PubMed]

88. Merino, P.; Diaz, A.; Jeanneret, V.; Wu, F.; Torre, E.; Cheng, L.; Yepes, M. Urokinase-type Plasminogen Activator (uPA) Binding to the uPA Receptor (uPAR) Promotes Axonal Regeneration in the Central Nervous System. J. Biol. Chem. 2017, 292, 2741-2753. [CrossRef]

89. Almholt, K.; Hebsgaard, J.B.; Nansen, A.; Andersson, C.; Pass, J.; Rono, B.; Thygesen, P.; Pelzer, H.; Loftager, M.; Lund, I.K.; et al. Antibody-Mediated Neutralization of uPA Proteolytic Function Reduces Disease Progression in Mouse Arthritis Models. J. Immunol. 2018, 200, 957-965. [CrossRef]

90. Thornton, S.; Raghu, H.; Cruz, C.; Frederick, M.D.; Palumbo, J.S.; Mullins, E.S.; Almholt, K.; Usher, P.A.; Flick, M.J. Urokinase plasminogen activator and receptor promote collagen-induced arthritis through expression in hematopoietic cells. Blood Adv. 2017, 1, 545-556. [CrossRef] 
91. Lund, I.K.; Illemann, M.; Thurison, T.; Christensen, I.J.; Hoyer-Hansen, G. uPAR as anti-cancer target: Evaluation of biomarker potential, histological localization, and antibody-based therapy. Curr. Drug Targets 2011, 12, 1744-1760. [CrossRef] [PubMed]

92. Kriegbaum, M.C.; Persson, M.; Haldager, L.; Alpízar-Alpízar, W.; Jacobsen, B.; Gårdsvoll, H.; Kjær, A.; Ploug, M. Rational Targeting of the Urokinase Receptor (uPAR): Development of Antagonists and Non-Invasive Imaging Probes. Curr. Drug Targets 2011, 12, 1711-1728. [CrossRef] [PubMed]

93. Persson, M.; Rasmussen, P.; Madsen, J.; Ploug, M.; Kjaer, A. New peptide receptor radionuclide therapy of invasive cancer cells: In vivo studies using 177Lu-DOTA-AE105 targeting uPAR in human colorectal cancer xenografts. Nucl. Med. Biol. 2012, 39, 962-969. [CrossRef]

94. Xu, D.; Bum-Erdene, K.; Si, Y.; Zhou, D.; Ghozayel, M.K.; Meroueh, S.O. Mimicking Intermolecular Interactions of Tight Protein-Protein Complexes for Small-Molecule Antagonists. ChemMedChem 2017, 12, 1794-1809. [CrossRef]

95. Ploug, M.; Ostergaard, S.; Gardsvoll, H.; Kovalski, K.; Holst-Hansen, C.; Holm, A.; Ossowski, L.; Dano, K. Peptide-derived antagonists of the urokinase receptor. affinity maturation by combinatorial chemistry, identification of functional epitopes, and inhibitory effect on cancer cell intravasation. Biochemistry 2001, 40, 12157-12168. [CrossRef] [PubMed]

96. Persson, M.; Hosseini, M.; Madsen, J.; Jorgensen, T.J.; Jensen, K.J.; Kjaer, A.; Ploug, M. Improved PET imaging of UPAR expression using new (64)Cu-labeled cross-bridged peptide ligands: Comparative in vitro and in vivo studies. Theranostics 2013, 3, 618-632. [CrossRef]

97. Persson, M.; Skovgaard, D.; Brandt-Larsen, M.; Christensen, C.; Madsen, J.; Nielsen, C.H.; Thurison, T.; Klausen, T.L.; Holm, S.; Loft, A.; et al. First-in-human uPAR PET: Imaging of Cancer Aggressiveness. Theranostics 2015, 5, 1303-1316. [CrossRef] [PubMed]

98. Ploug, M. Structure-driven design of radionuclide tracers for non-invasive imaging of uPAR and targeted radiotherapy. The tale of a synthetic peptide antagonist. Theranostics 2013, 3, 467-476. [CrossRef]

99. Boonstra, M.C.; Van Driel, P.; Keereweer, S.; Prevoo, H.; Stammes, M.A.; Baart, V.M.; Lowik, C.; Mazar, A.P.; van de Velde, C.J.H.; Vahrmeijer, A.L.; et al. Preclinical uPAR-targeted multimodal imaging of locoregional oral cancer. Oral Oncol. 2017, 66, 1-8. [CrossRef]

100. Kurbegovic, S.; Juhl, K.; Chen, H.; Qu, C.; Ding, B.; Leth, J.M.; Drzewiecki, K.T.; Kjaer, A.; Cheng, Z. Molecular Targeted NIR-II Probe for Image-Guided Brain Tumor Surgery. Bioconjugate Chem. 2018, 29, 3833-3840. [CrossRef]

101. Huai, Q.; Zhou, A.; Lin, L.; Mazar, A.P.; Parry, G.C.; Callahan, J.; Shaw, D.E.; Furie, B.; Furie, B.C.; Huang, M. Crystal structures of two human vitronectin, urokinase and urokinase receptor complexes. Nat. Struct. Mol. Biol. 2008, 15, 422-423. [CrossRef]

102. Gardsvoll, H.; Jacobsen, B.; Kriegbaum, M.C.; Behrendt, N.; Engelholm, L.; Ostergaard, S.; Ploug, M. Conformational regulation of urokinase receptor function: Impact of receptor occupancy and epitope-mapped monoclonal antibodies on lamellipodia induction. J. Biol. Chem. 2011, 286, 33544-33556. [CrossRef]

103. Gardsvoll, H.; Kjaergaard, M.; Jacobsen, B.; Kriegbaum, M.C.; Huang, M.; Ploug, M. Mimicry of the regulatory role of urokinase in lamellipodia formation by introduction of a non-native interdomain disulfide bond in its receptor. J. Biol. Chem. 2011, 286, 43515-43526. [CrossRef] [PubMed]

104. Xu, X.; Gardsvoll, H.; Yuan, C.; Lin, L.; Ploug, M.; Huang, M. Crystal structure of the urokinase receptor in a ligand-free form. J. Mol. Biol. 2012, 416, 629-641. [CrossRef] [PubMed]

105. Zhao, B.; Gandhi, S.; Yuan, C.; Luo, Z.; Li, R.; Gardsvoll, H.; de Lorenzi, V.; Sidenius, N.; Huang, M.; Ploug, M. Stabilizing a flexible interdomain hinge region harboring the SMB binding site drives uPAR into its closed conformation. J. Mol. Biol. 2015, 427, 1389-1403. [CrossRef] [PubMed]

106. Mertens, H.D.; Kjaergaard, M.; Mysling, S.; Gardsvoll, H.; Jorgensen, T.J.; Svergun, D.I.; Ploug, M. A flexible multidomain structure drives the function of the urokinase-type plasminogen activator receptor (uPAR). J. Biol. Chem. 2012, 287, 34304-34315. [CrossRef] [PubMed]

107. Leth, J.M.; Mertens, H.D.; Leth-Espernsen, K.Z.; Jørgensen, T.J.D.; Ploug, M. Did evolution create a flexible ligand-binding cavity in the urokinase receptor through deletion of a plesiotypic disulfide bond? J. Biol. Chem. 2019, 294, 7403-7418. [CrossRef]

108. Chana-Muñoz, A.; Jendroszek, A.; Sønnichsen, M.; Wang, T.; Ploug, M.; Jensen, J.K.; Andreasen, P.A.; Bendixen, C.; Panitz, F. Origin and diversification of the plasminogen activation system among chordates. BMC Evol. Biol. 2019, 19. [CrossRef] 
109. Hansen, L.V.; Gardsvoll, H.; Nielsen, B.S.; Lund, L.R.; Dano, K.; Jensen, O.N.; Ploug, M. Structural analysis and tissue localization of human C4.4A: A protein homologue of the urokinase receptor. Biochem. J. 2004, 380, 845-857. [CrossRef] [PubMed]

110. Kriegbaum, M.C.; Clausen, O.P.; Laerum, O.D.; Ploug, M. Expression of the Ly6/uPAR-domain proteins C4.4A and Haldisin in non-invasive and invasive skin lesions. J. Histochem. Cytochem. 2015, 63, 142-154. [CrossRef]

111. Kriegbaum, M.C.; Jacobsen, B.; Hald, A.; Ploug, M. Expression of C4.4A, a structural uPAR homolog, reflects squamous epithelial differentiation in the adult mouse and during embryogenesis. J. Histochem. Cytochem. 2011, 59, 188-201. [CrossRef] [PubMed]

112. Gårdsvoll, H.; Kriegbaum, M.C.; Hertz, E.P.; Alpízar-Alpízar, W.; Ploug, M. The Urokinase Receptor Homolog Haldisin Is a Novel Differentiation Marker of Stratum Granulosum in Squamous Epithelia. J. Histochem. Cytochem. 2013, 61, 802-813. [CrossRef] [PubMed]

113. Kriegbaum, M.C.; Jacobsen, B.; Fuchtbauer, A.; Hansen, G.H.; Christensen, I.J.; Rundsten, C.F.; Persson, M.; Engelholm, L.H.; Madsen, A.N.; Di Meo, I.; et al. C4.4A gene ablation is compatible with normal epidermal development and causes modest overt phenotypes. Sci. Rep. 2016, 6, 25833. [CrossRef] [PubMed]

114. Hansen, L.V.; Skov, B.G.; Ploug, M.; Pappot, H. Tumour cell expression of C4.4A, a structural homologue of the urokinase receptor, correlates with poor prognosis in non-small cell lung cancer. Lung Cancer 2007, 58, 260-266. [CrossRef] [PubMed]

115. Jacobsen, B.; Muley, T.; Meister, M.; Dienemann, H.; Christensen, I.J.; Santoni-Rugiu, E.; Laerum, O.D.; Ploug, M. Ly6/uPAR-related protein C4.4A as a marker of solid growth pattern and poor prognosis in lung adenocarcinoma. J. Thorac. Oncol. 2013, 8, 152-160. [CrossRef] [PubMed]

116. Jacobsen, B.; Santoni-Rugiu, E.; Illemann, M.; Kriegbaum, M.C.; Laerum, O.D.; Ploug, M. Expression of C4.4A in precursor lesions of pulmonary adenocarcinoma and squamous cell carcinoma. Int. J. Cancer 2012, 130, 2734-2739. [CrossRef] [PubMed]

117. Hinck, A.P.; Mueller, T.D.; Springer, T.A. Structural Biology and Evolution of the TGF-beta Family. Cold Spring Harb. Perspect. Biol. 2016, 8, a022103. [CrossRef]

118. Keller, S.; Nickel, J.; Zhang, J.L.; Sebald, W.; Mueller, T.D. Molecular recognition of BMP-2 and BMP receptor IA. Nat. Struct. Mol. Biol 2004, 11, 481-488. [CrossRef]

119. Mace, P.D.; Cutfield, J.F.; Cutfield, S.M. High resolution structures of the bone morphogenetic protein type II receptor in two crystal forms: Implications for ligand binding. Biochem. Biophys. Res. Commun. 2006, 351, 831-838. [CrossRef]

120. Zhao, Y.; Ren, J.; Lu, W.; Harlos, K.; Jones, E.Y. Structure of the Wnt signaling enhancer LYPD6 and its interactions with the Wnt coreceptor LRP6. FEBS Lett. 2018, 592, 3152-3162. [CrossRef] 